\title{
Article \\ Tumor Necrosis Factor Alpha Effects on the Porcine Intestinal Epithelial Barrier Include Enhanced Expression of TNF Receptor 1
}

\author{
Linda Droessler $\left.^{1}{ }^{(}\right)$, Valeria Cornelius ${ }^{1}\left(\mathbb{D}\right.$, Alexander G. Markov ${ }^{2}\left({ }^{\oplus}\right.$ and Salah Amasheh ${ }^{1, *}$ \\ 1 Institute of Veterinary Physiology, Department of Veterinary Medicine, Freie Universität Berlin, \\ 14163 Berlin, Germany; linda.droessler@fu-berlin.de (L.D.); valeria.cornelius@fu-berlin.de (V.C.) \\ 2 Department of General Physiology, Faculty of Biology, Saint Petersburg State University, \\ Universitetskaya nab., 7-9, 199034 Saint Petersburg, Russia; a.markov@spbu.ru \\ * Correspondence: salah.amasheh@fu-berlin.de; Tel.: +49-30-838-62602; Fax: +49-30-838-462602
}

check for updates

Citation: Droessler, L.; Cornelius, V.; Markov, A.G.; Amasheh, S. Tumor Necrosis Factor Alpha Effects on the Porcine Intestinal Epithelial Barrier Include Enhanced Expression of TNF Receptor 1. Int. J. Mol. Sci. 2021, 22, 8746. https://doi.org/10.3390/ ijms22168746

Academic Editors: Maria Luisa Balestrieri and Gautam Sethi

Received: 6 July 2021

Accepted: 11 August 2021

Published: 14 August 2021

Publisher's Note: MDPI stays neutral with regard to jurisdictional claims in published maps and institutional affiliations.

Copyright: (c) 2021 by the authors. Licensee MDPI, Basel, Switzerland. This article is an open access article distributed under the terms and conditions of the Creative Commons Attribution (CC BY) license (https:/ / creativecommons.org/licenses/by/ $4.0 /)$.

\begin{abstract}
Tumor necrosis factor alpha $(\mathrm{TNF} \alpha)$ has been shown to impair the intestinal barrier, inducing and maintaining inflammatory states of the intestine. The aim of the current study was to analyze functional, molecular and regulatory effects of TNF $\alpha$ in a newly established non-transformed jejunal enterocyte model, namely IPEC-J2 monolayers. Incubation with $1000 \mathrm{U} / \mathrm{mL}$ TNF $\alpha$ induced a marked decrease in transepithelial electrical resistance (TEER), and an increase in permeability for the paracellular flux marker $\left[{ }^{3} \mathrm{H}\right]$-D-mannitol compared to controls. Immunoblots revealed a significant decrease in tight junction (TJ) proteins occludin, claudin- 1 and claudin- 3 . Moreover, a dose-dependent increase in the TNF receptor (TNFR)-1 was detected, explaining the exponential nature of pro-inflammatory effects, while TNFR-2 remained unchanged. Recovery experiments revealed reversible effects after the removal of the cytokine, excluding apoptosis as a reason for the observed changes. Furthermore, TNF $\alpha$ signaling could be inhibited by the specific myosin light chain kinase (MLCK) blocker ML-7. Results of confocal laser scanning immunofluorescence microscopy were in accordance with all quantitative changes. This study explains the self-enhancing effects of TNF $\alpha$ mediated by MLCK, leading to a differential regulation of TJ proteins resulting in barrier impairment in the intestinal epithelium.
\end{abstract}

Keywords: claudins; epithelial barrier; IPEC-J2; ML-7; tight junction; TNF $\alpha$; TNFR-1

\section{Introduction}

The intestinal epithelial paracellular barrier is essential since it prevents the immune system from being overly induced by a wide variety of exogenous antigens and microorganisms. Tight junctions (TJs), which are formed in strands and located at the apicolateral membrane of adjacent cells, represent the functional correlate of the epithelial paracellular barrier function. These TJ strands are defined by the common presence of several integral membrane proteins, such as occludin [1], junctional adhesion molecule (JAM) [2] or the claudin protein family, from which at least 27 members are known [3]. Along the longitudinal axis of the gastrointestinal tract, a strong correlation of TJ protein expression and barrier properties has been demonstrated [4]. In inflammatory bowel disease (IBD), increased paracellular permeability due to a lack or disruption of TJ proteins results in intestinal inflammation and may cause diarrhea [5].

The proinflammatory cytokine tumor necrosis factor $\alpha(\mathrm{TNF} \alpha)$ plays a key role in the pathogenesis of IBD, and thus has been shown to be increased in patients with Crohn's disease (CD) or ulcerative colitis (UC) [6,7]. One potential proinflammatory action of TNF $\alpha$ is the ability to alter the intestinal epithelial TJ composition, leading to an increase in paracellular permeability and a decrease in transepithelial electrical resistance (TEER) $[8,9]$. Sealing TJ proteins, such as claudin-1, -7 or occludin, have been reported to be a primary 
target affected by incubation with TNF $\alpha$ [10], and the molecular changes in TJ composition cause a disturbance in intestinal epithelial barrier function and provoke diarrhea [11,12]. Although the exact mechanisms of TNF $\alpha$ on TJ composition have not been analyzed in detail, the myosin light chain kinase (MLCK) appears to be involved in intestinal barrier disturbance, as increased MLCK production can be observed after TNF $\alpha$ treatment [13-15]. One function of MLCK is to phosphorylate the myosin light chain (MLC), resulting in a contraction of actin and therefore rearranging the cytoskeleton [16,17]. In several inflammatory diseases, such as IBD, an enhanced expression of MLCK has been observed, leading to impaired epithelial barrier function [16]. The activation of MLCK by TNF $\alpha$ leads to a reorganization of TJ proteins and therefore affects the paracellular barrier [18].

The permanent porcine intestinal epithelial cell line IPEC-J2, a non-transformed cell line obtained from jejunal epithelia of an unsuckled piglet, has been characterized as a suitable in vitro intestinal model [19]. Due to its capacity to grow as a monolayer and form an apical and a basolateral compartment, as well as apicolateral junctional complexes, it can be useful for the analysis of the paracellular barrier and permeability. By culturing this cell line under species-specific conditions, using porcine serum (PS) instead of conventional serum, IPEC-J2 cells constitute an improved model for the analysis of porcine jejunal barrier function in vitro [20]. On account of the great similarities between the anatomy and physiology of swine and humans, the pig provides an extremely valuable model for studies compared to other animal models [21], as it is in accordance with human nutritional and digestive effects and mechanisms [22].

The barrier-weakening effect of TNF $\alpha$ has been evaluated on various cell culture models, such as the rat ileal intestinal epithelial cell line IEC-18 [23] or the human carcinogenic cell lines Caco-2 [24,25] and HT-29/B6 [10,26,27], but not in detail on the non-transformed porcine intestinal epithelial cell line IPEC-J2 so far. Therefore, our study aimed to analyze the effect of TNF $\alpha$ on the barrier function as well as the TJ composition of IPEC-J2 cells. This was assessed by the measurement of TEER and $\left[{ }^{3} \mathrm{H}\right]$-D-Mannitol flux during treatment with the cytokine. Subsequent to the incubation experiments, the TJ composition was analyzed in detail and the impact of TNF $\alpha$ on the density of tumor necrosis factor receptor 1 and 2 (TNFR-1, TNFR-2) was investigated. As MLCK has been discussed in context with barrier perturbation in a series of studies, further experiments were carried out using a specific blocker against MLCK to analyze the signaling cascade of TNF $\alpha$ on IPEC-J2 cells. This provides new experimental data, showing that (i) the non-transformed cell line IPEC-J2 represents a useful model for the exploration of inflammation-induced changes in porcine intestinal epithelial barrier function and (ii) explains the self-enhancing effects of TNF $\alpha$ resulting in TJ impairment in the intestinal epithelium on a functional, molecular and regulatory level.

\section{Results}

\subsection{Effects of TNF $\alpha$ on Epithelial Barrier Function of IPEC-J2}

To examine the effects of TNF $\alpha$ on the transepithelial barrier function of the porcine jejunal cell line IPEC-J2, concentration-dependent effects of the cytokine were analyzed by addition to the basolateral compartment of the cells, and TEER and $\left[{ }^{3} \mathrm{H}\right]$-D-Mannitol flux were measured. After $48 \mathrm{~h}, 1000 \mathrm{U} / \mathrm{mL}$ and $5000 \mathrm{U} / \mathrm{mL} \mathrm{TNF} \alpha$ showed a marked decrease in TEER compared to the control group (one-way ANOVA: $\mathrm{F}(5,109)=9.22, p<0.0001$, $n=14-22$; ctrl: $101.06 \pm 2.89 \%$; $1000 \mathrm{U} / \mathrm{mL}: 88.45 \pm 2.56 \%, p=0.0113 ; 5000 \mathrm{U} / \mathrm{mL}$ : $78.74 \pm 3.19 \%, p<0.0001$, Figure 1A). With lower concentrations of TNF $\alpha$, TEER remained unchanged over the whole incubation period $(50 \mathrm{U} / \mathrm{mL}: 97.47 \pm 1.93 \%, p=0.91 ; 100 \mathrm{U} / \mathrm{mL}$ : $102.21 \pm 5.41 \%, p=0.99 ; 500 \mathrm{U} / \mathrm{mL}: 98.49 \pm 2.35 \%, p=0.96)$. Hence, the following experiments were carried out using concentrations of $1000 \mathrm{U} / \mathrm{mL} \mathrm{TNF} \alpha$. After $24 \mathrm{~h}$, $1000 \mathrm{U} / \mathrm{mL}$ did not have significant effects on TEER (ctrl: $93.81 \pm 1.81 \% ; 1000 \mathrm{U} / \mathrm{mL}$ : $92.96 \pm 3.60 \%, p=0.99, n=23$; Figure 1B). 
A

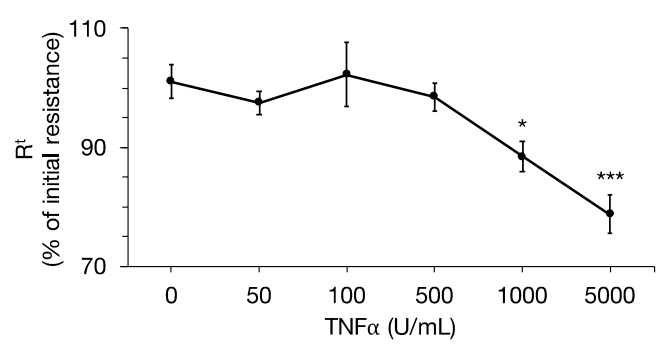

B

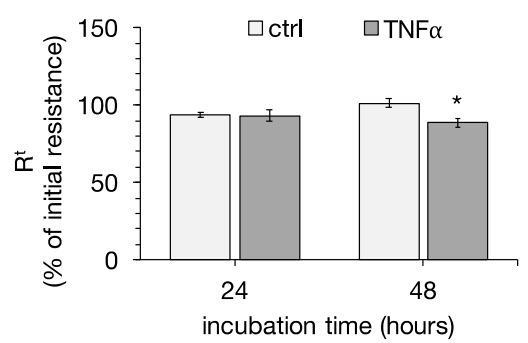

C

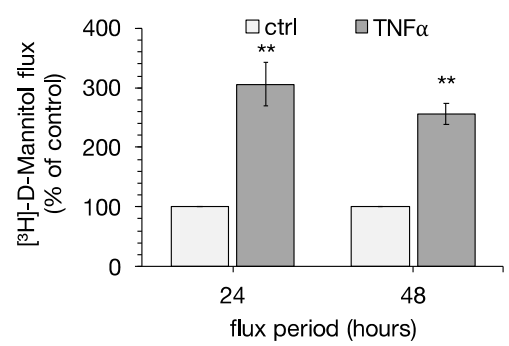

Figure 1. (A) To examine the dose-dependent effect of tumor necrosis factor $\alpha$ (TNF $\alpha)$ on IPEC-J2 cells, increasing concentrations were added basolateral to the monolayers and transepithelial electrical resistance (TEER) was measured for $48 \mathrm{~h}$. Concentrations of $1000 \mathrm{U} / \mathrm{mL}$ and $5000 \mathrm{U} / \mathrm{mL}$ revealed a decrease in TEER in IPEC-J2 cells (one-way ANOVA, $\left.{ }^{*} p<0.05,{ }^{* * *} p<0.001 ; n=14-22\right)$. Therefore, following experiments were carried out using $1000 \mathrm{U} / \mathrm{mL}$. (B) No significant changes in TEER could be observed after $24 \mathrm{~h}$ with $1000 \mathrm{U} / \mathrm{mL}$ TNF $\alpha$. (C) Flux measurements using [ $\left.{ }^{3} \mathrm{H}\right]-\mathrm{D}-\mathrm{Mannitol}$ revealed an increased paracellular flux after 24 as well as $48 \mathrm{~h}$ (unpaired $t$-test, ${ }^{* *} p<0.01, n=6$ ). Resistance values are expressed as percentage of initial resistance and compared to controls, respectively. For analysis of paracellular flux, controls were set to $100 \%$ and values were compared to this, respectively. All data shown are presented as means \pm SEM.

For permeability studies, unidirectional paracellular tracer flux from the apical to the basolateral side of the cell culture filters was measured using $\left[{ }^{3} \mathrm{H}\right]-\mathrm{D}-\mathrm{Mannitol}$. The control groups were set to $100 \%$ and flux measurements of $\mathrm{TNF} \alpha$-incubated cell filters were compared to control groups, respectively. For the first flux period of $24 \mathrm{~h}, 1000 \mathrm{U} / \mathrm{mL}$ $\mathrm{TNF} \alpha$ indicated a stronger paracellular permeability compared to the control groups (ctrl: $100 \% ; \mathrm{TNF} \alpha: 306.18 \pm 59.76 \%, p=0.006, n=6)$. The same effect could be observed in the second flux period from 24 to $48 \mathrm{~h}$ (ctrl: $100 \%$; TNF $\alpha$ : $256.32 \pm 40.91 \%, p=0.003, n=6$; Figure 1C).

\subsection{Western Blot and Densitometry of TJ Proteins}

Following electrophysiological measurements, protein samples of the cells were used for immunoblotting, analyzing TJ proteins claudin-1, -3, -4, -7, occludin and ZO-1. For densitometry, the protein levels of the specific bands were normalized on total protein amount. The protein expression of untreated cells was normalized to $100 \%$ and the TNF $\alpha$-treated groups were compared to controls, respectively. Densitometric analysis of immunoblots revealed a significant decrease in claudin-1 expression in IPEC-J2 cells after treatment with TNF $\alpha$ for $48 \mathrm{~h}(51.94 \pm 4.52 \%, p<0.0001, n=6)$. The same effect could be observed for claudin-3 $(52.51 \pm 16.09 \%, p=0.012, n=6)$, as well as for occludin expression $(65.57 \pm 12.31 \%, p=0.019, n=6)$. The expression of the TJ proteins claudin- $4,-7$ and $\mathrm{ZO}-1$ did not significantly change during TNF $\alpha$ treatment (claudin-4: $87.39 \pm 10.37 \%, p=0.25$; claudin-7: $82.99 \pm 7.77 \%, p=0.054 ; \mathrm{ZO}-1: 99.36 \pm 20.82 \%, p=0.98 ; n=6$, Figure $2 \mathrm{~A}, \mathrm{~B})$.

\subsection{Immunohistochemistry of TJ Proteins}

As the incubation with TNF $\alpha$ led to changes in the expression levels of claudin-1, -3 and occludin in IPEC-J2 cells, confocal laser scanning immunofluorescence was performed to examine the localization of these TJ proteins. After $48 \mathrm{~h}$ incubation with TNF $\alpha$, the claudin-1 signal (green, Figure 3A) no longer appeared as fine paracellular lines as seen for the controls, but rather as washed-out lines with a weaker signal. The ZO-1 signal remained mostly unaltered over the whole incubation period (red, Figure 3A). In Figure 3B, a co-localization of claudin-3 (green) and occludin (red), resulting in a yellow signal in merged confocal images, could be shown by double staining. TNF $\alpha$ caused an evident loss of specific claudin-3 and occludin immunofluorescence signals from the apicolateral membrane (Figure 3B), which correlates with the changes in the expression levels of claudin-3 and occludin. 
A

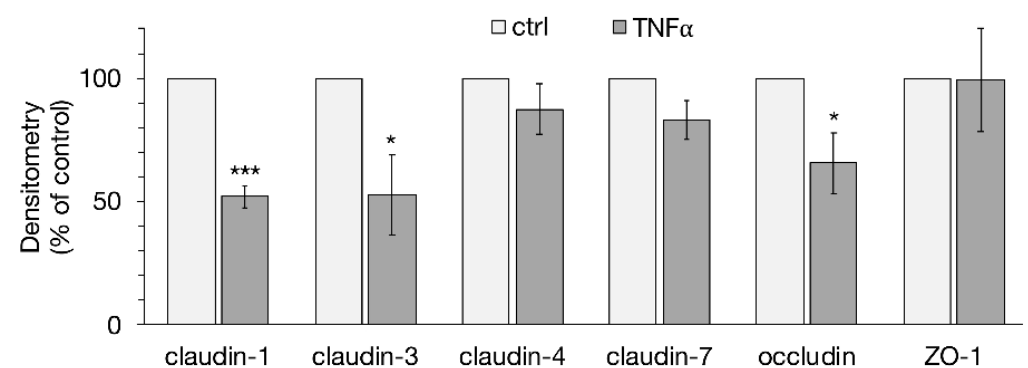

B

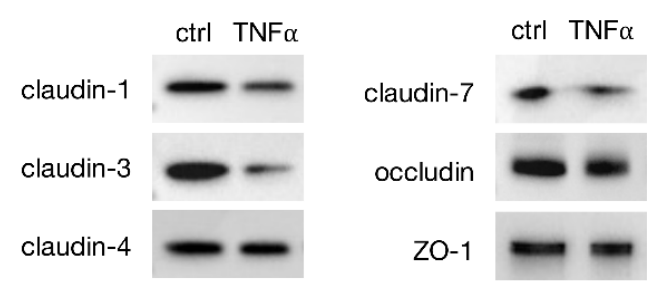

Figure 2. (A) Densitometry and (B) representative Western blot bands of tight junction (TJ) proteins after TNF $\alpha$ incubation revealed significantly weaker expression of claudin- $1,-3$ and occludin compared to controls, while claudin- $4,-7$ and ZO-1 remained unaffected (unpaired $t$-test, ${ }^{*} p<0.05,{ }^{* * *} p<0.001 ; n=6$ ). For Western blot analysis, the specific bands were normalized on total protein amount. All data presented are stated in means \pm SEM.

\section{A}

DAPI
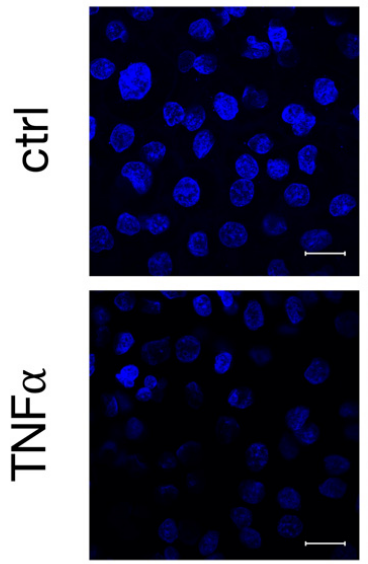

B
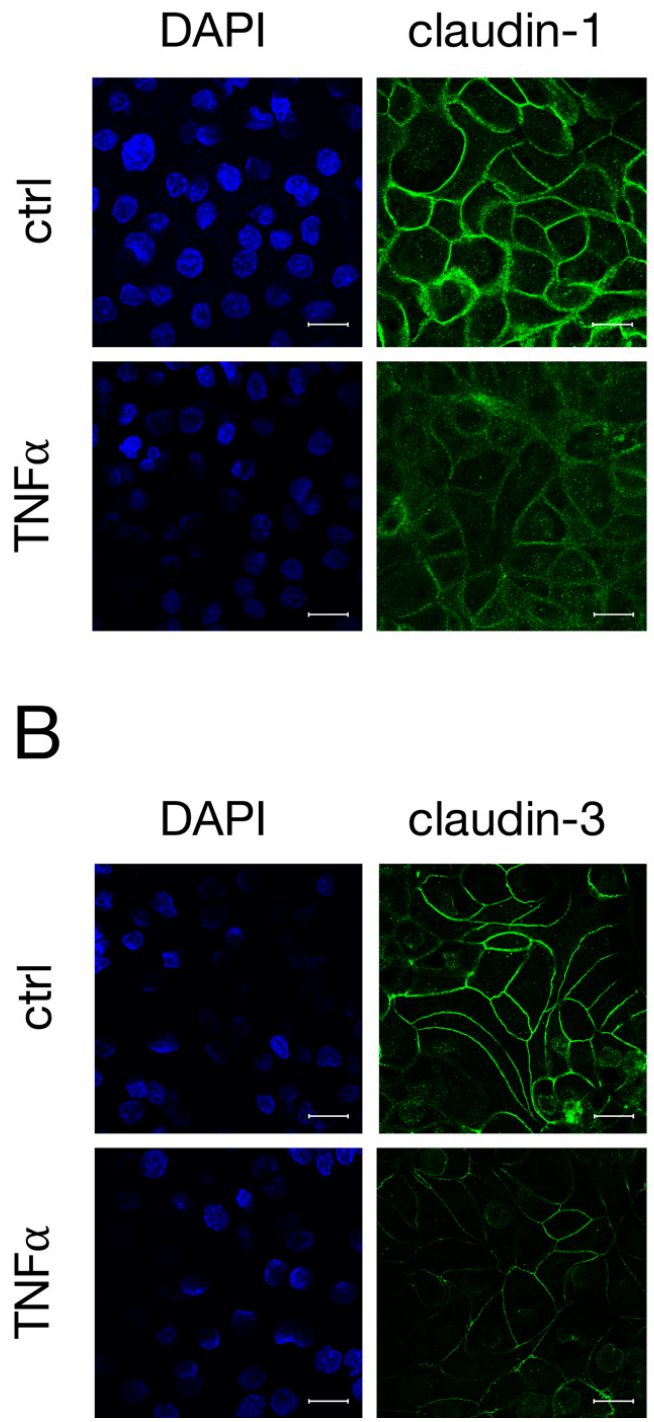
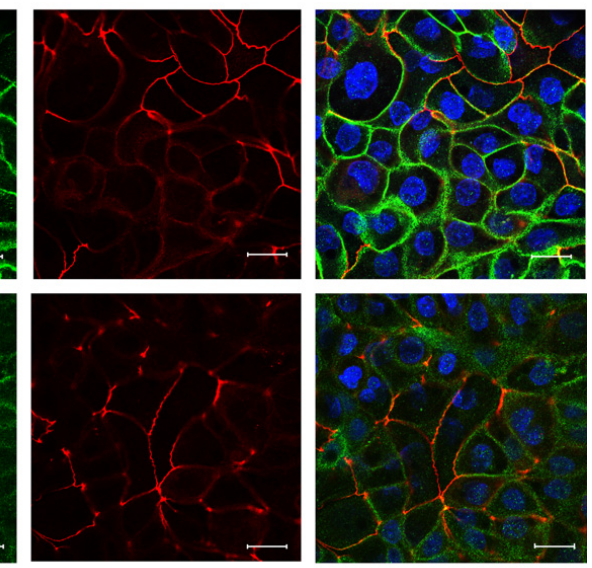

occludin
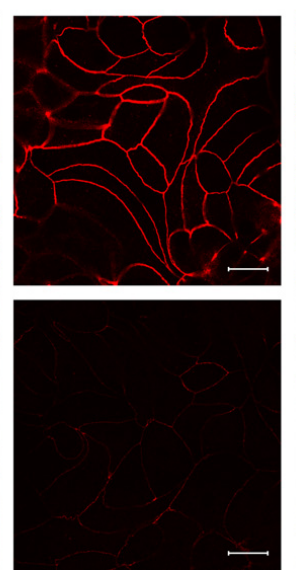

merge
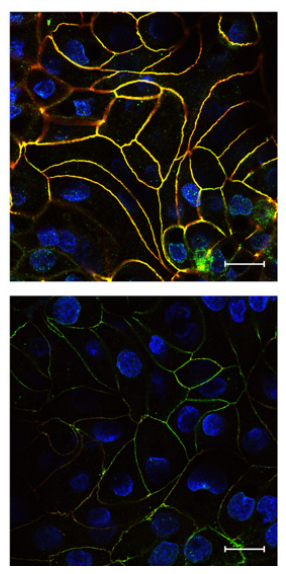

Figure 3. Confocal laser scanning immunofluorescence microscopy was performed to analyze the localization of (A) claudin-1 (green) and ZO-1 (red), or (B) claudin-3 (green) and occludin (red) after incubation with TNF $\alpha$ for $48 \mathrm{~h}$. Nuclei were stained in blue (DAPI). Claudin-3 shows a strong colocalization with occludin (merge, yellow signal, B) (scale bar: $20 \mu \mathrm{m} ; n=4$; representative pictures). 


\subsection{TNFR-1 and TNFR-2 Expression Level}

Western blot analysis was performed to investigate whether the incubation with TNF $\alpha$ has any effect on the expression of TNFR-1 or -2. After normalization on total protein amount, the control groups were set to $100 \%$ and the $\mathrm{TNF} \alpha$-treated groups were compared to them, respectively. After $48 \mathrm{~h}$ with 500, 1000 and $5000 \mathrm{U} / \mathrm{mL}$ TNF $\alpha$, a marked upregulation of TNFR-1 expression could be observed (one-way ANOVA: F $(3,12)=9.70$, $p=0.0016, n=4 ; 500 \mathrm{U} / \mathrm{mL}: 168.34 \pm 7.77 \%, p=0.0036 ; 1000 \mathrm{U} / \mathrm{mL}: 159.08 \pm 14.90 \%$, $p=0.0098 ; 5000 \mathrm{U} / \mathrm{mL}: 182.35 \pm 16.10 \%, p=0.0008$; Figure 4). Conversely, the densitometric analysis of TNFR-2 did not show any significant changes due to TNF $\alpha$ treatment (one-way ANOVA: $\mathrm{F}(3,12)=0.46, p=0.71, n=4 ; 500 \mathrm{U} / \mathrm{mL}: 113.23 \pm 24.21 \%, p=0.87 ; 1000 \mathrm{U} / \mathrm{mL}$ : $88.00 \pm 13.26 \%, p=0.89 ; 5000 \mathrm{U} / \mathrm{mL}: 101.89 \pm 12.57 \%, p=0.99)$.

A

$0 \quad 500 \quad 10005000$ $\mathrm{U} / \mathrm{mL} \mathrm{U} / \mathrm{mL} \mathrm{U} / \mathrm{mL} \mathrm{U} / \mathrm{mL}$

TNFR-1

TNFR-2

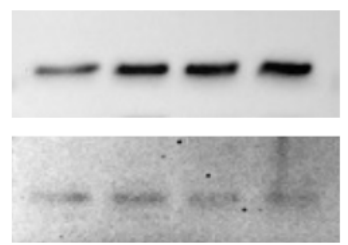

B

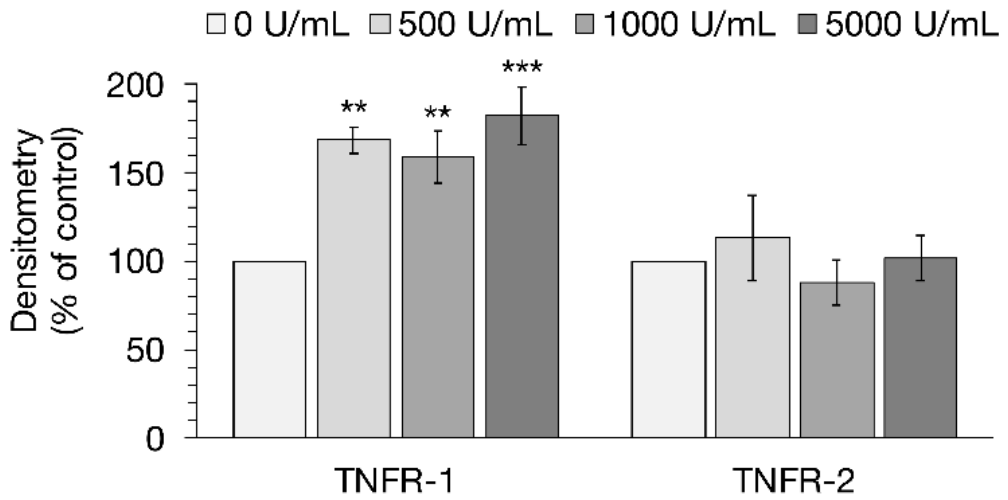

Figure 4. (A) Representative Western blot bands and (B) Densitometry of TNFR-1 and TNFR-2 after $48 \mathrm{~h}$ incubation with rising TNF $\alpha$ concentrations $(500,1000,5000 \mathrm{U} / \mathrm{mL})$. After specific protein bands were normalized on total protein amount, the protein expression of untreated cells was normalized to $100 \%$ and groups treated with TNF $\alpha$ were compared to this, respectively. Incubation with the cytokine led to a clear increase in TNFR-1 expression, while TNFR-2 remained unchanged. Data are shown in mean \pm SEM (one-way ANOVA, ${ }^{* *} p<0.01$, ${ }^{* * *} p<0.001 ; n=4$ ).

\subsection{Confocal Laser Scanning Immunofluorescence Microscopy of TNFR-1}

In addition to changes on the expression of TNFR-1, we aimed to analyze whether TNF $\alpha$ also leads to an altered localization of TNFR-1 in IPEC-J2. Therefore, cells were stained with TNFR-1 and ITG $\beta 1$, an integral membrane protein that is located at the basolateral membrane of cells [28]. With rising TNF $\alpha$ concentrations, a stronger signal for TNFR-1 (green, Figure 5A) could be observed, while the signal for ITG $\beta 1$ (red, Figure 5A) remained unchanged due to the incubation with TNF $\alpha$. The co-localization of TNFR-1 with ITG $\beta 1$, resulting in the basolateral localization of TNFR-1, can be seen as a yellow signal in the merged pictures. Additionally, Z-stack images were performed to investigate the localization of TNFR-1 more precisely. In Figure 5B, the weak TNFR-1 signal (green) is solely orientated to the basal and basolateral membrane, which is pointed out by white arrows. After incubation with $5000 \mathrm{U} / \mathrm{mL}$ TNF $\alpha$, the TNFR-1 signal appears entirely stronger and a localization, not only on the basolateral membranes of the cells, but also on the apical membrane, can be observed (Figure 5C). 


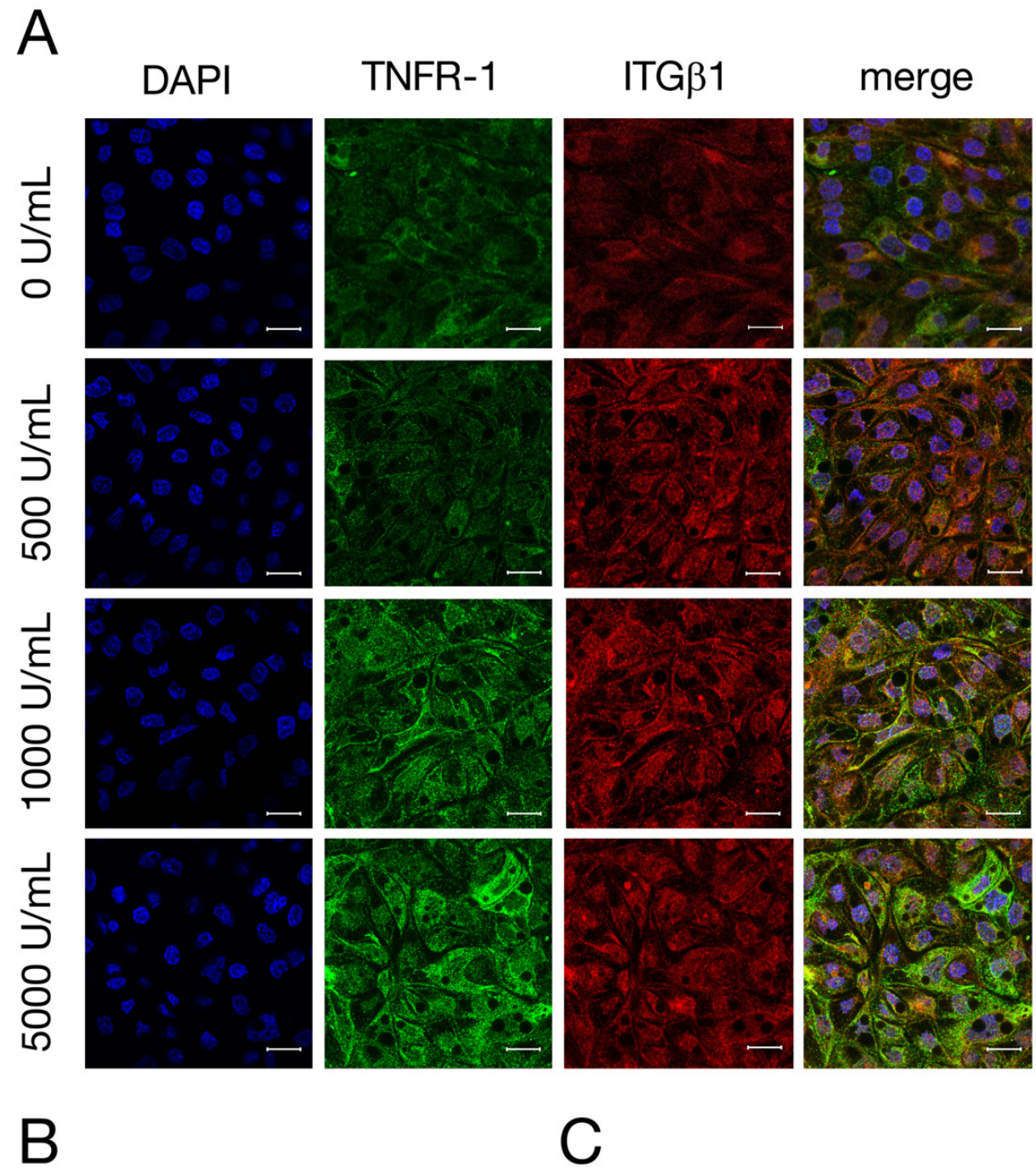

$0 \mathrm{U} / \mathrm{mL}$

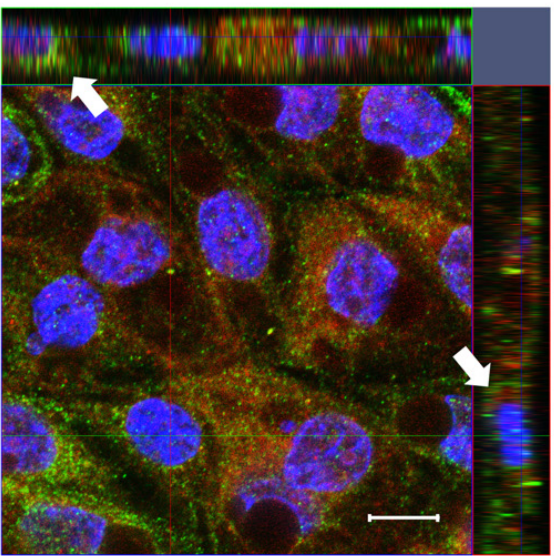

$5000 \mathrm{U} / \mathrm{mL}$

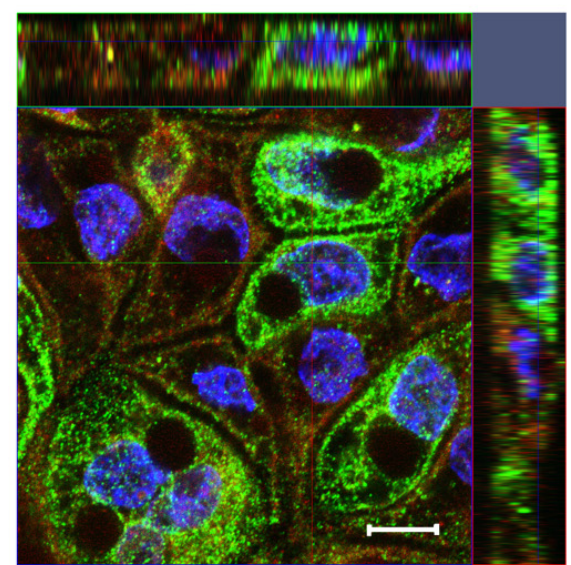

Figure 5. (A) To analyze the localization of TNFR-1 after incubation with different concentrations of $\mathrm{TNF} \alpha(500,1000,5000 \mathrm{U} / \mathrm{mL})$ for $48 \mathrm{~h}$, confocal laser scanning immunofluorescence microscopy of TNFR-1 (green) and ITG $\beta 1$ (red, A) was performed. The colocalization of TNFR-1 with ITG $\beta 1$ can be seen as a yellow signal in the merged pictures. Nuclei were stained in blue (DAPI). In addition, Z-stack images with $(\mathbf{C})$ or without $(\mathbf{B}) \mathrm{TNF} \alpha$ were recorded for a more detailed analysis of the localization of TNFR-1. (B) White arrows point out the basal side of the cells (scale bar: A $20 \mu \mathrm{m}$; $\mathrm{B}, \mathrm{C} 40 \mu \mathrm{m} ; n=3$; representative images). 


\subsection{Signaling Experiments with Specific MLCK Blocker}

We used ML-7, a specific MLCK blocker, to analyze the signaling of TNF $\alpha$-induced changes in epithelial barrier function in more detail. After $48 \mathrm{~h}$, cells treated with TNF $\alpha$ together with ML-7 showed a significant difference compared to cells treated solely with TNF $\alpha$ (one-way ANOVA: F $(2,41)=15.37, p<0.0001, n=7-29$; TNF $\alpha: 92.38 \pm 2.66 \%$; $\mathrm{TNF} \alpha+$ ML-7: $113.76 \pm 5.69 \%, p=0.0053)$. Comparable results could be seen between cells treated with TNF $\alpha$ and control groups (TNF $\alpha$ : $92.38 \pm 2.66 \%$; ctrl: $126.50 \pm 8.61 \%$; $p<0.0001$; Figure 6A). To investigate whether these changes are in connection with the altered expression of TJ proteins, immunoblot analysis was subsequently performed (Figure 6B,C). Densitometric analysis revealed that ML-7 almost completely averted the decrease in claudin-3 expression after treatment with TNF $\alpha$ (Kruskal-Wallis test: H (2) $=9.37$, $p=0.009, n=4 ; \mathrm{TNF} \alpha: 69.18 \pm 10.86 \% ; \mathrm{TNF} \alpha+\mathrm{ML}-7: 95.58 \pm 1.68 \%, p=0.04)$. While the expression of claudin- 1 was also notably higher with TNF $\alpha$ and ML-7 compared to cells treated only with $\mathrm{TNF} \alpha$, just a tendency towards significance could be shown (one-way ANOVA: $\mathrm{F}(2,9)=5.30, p=0.03, n=4$; TNF $\alpha$ : $69.34 \pm 5.08 \%$; TNF $\alpha+$ ML-7: $94.31 \pm 11.17 \%$, $p=0.079)$. Surprisingly, treatment with the MLCK blocker did not affect the expression of occludin (Kruskal-Wallis test: H (2) $=7.65, p=0.02, n=4$; TNF $\alpha$ : $50.76 \pm 10.04 \%$; TNF $\alpha+$ ML-7: $50.28 \pm 12.91 \% ; p=1.00)$. The strong increase in TNFR-1 due to TNF $\alpha$ incubation was also inhibited by ML-7 (Kruskal-Wallis test: $\mathrm{H}(2)=9.09, p=0.01, n=4$; $\mathrm{TNF} \alpha: 160.70 \pm 12.04 \% ; \mathrm{TNF} \alpha+\mathrm{ML}-7: 117.57 \pm 11.32 \% ; p=0.026)$.

A

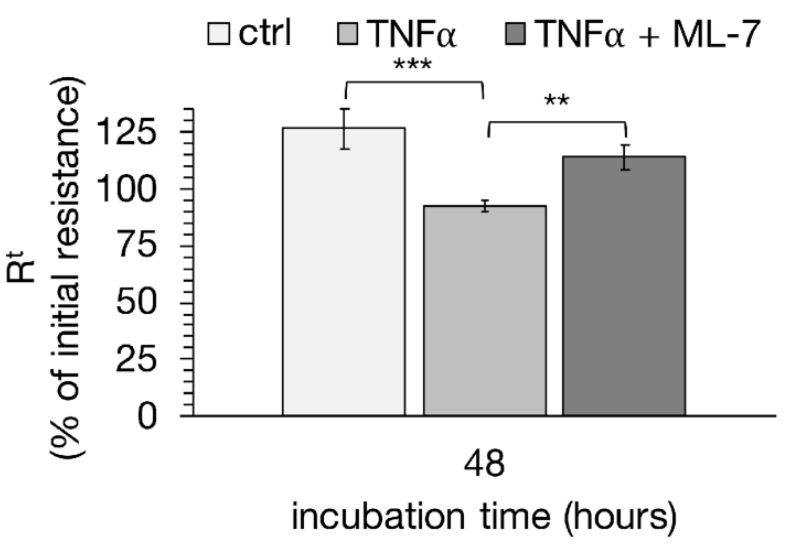

B

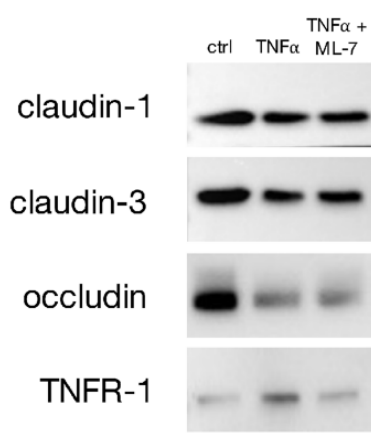

C
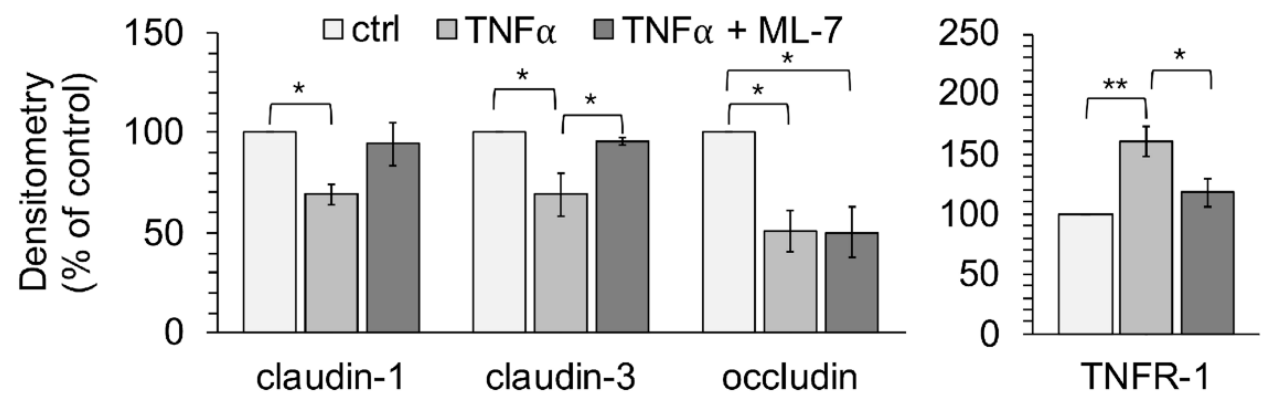

Figure 6. Effects of ML-7, a specific MLCK blocker, were studied after TNF $\alpha$ incubation using TEER measurements and Western blot analysis. (A) After $48 \mathrm{~h}$, the groups treated solely with TNF $\alpha$ showed a significant difference in TEER compared to controls and cells treated with TNF $\alpha$ and ML-7 (one-way ANOVA, ${ }^{* *} p<0.01,{ }^{* * *} p<0.001 ; n=7-29$ ). (B) Representative Western blot bands and (C) densitometry after $48 \mathrm{~h}$ with TNF $\alpha$ in the presence or absence of ML-7 revealed that the MLCK blocker prevented the TNF $\alpha$-induced decrease in claudin-1 and -3 , while the decrease in occludin was not affected. Furthermore, the TNF $\alpha$-induced increase in TNFR- 1 is also inhibited by ML-7. Data are presented as mean $\pm \operatorname{SEM}\left({ }^{*} p<0.05\right.$, ** $p<0.01 ; n=4)$. 
Subsequently, confocal laser scanning immunofluorescence microscopy was carried out after $48 \mathrm{~h}$ to see whether ML-7 is also capable of inhibiting the changed localization of TJ proteins caused by TNF $\alpha$. As shown in Figure 7A, the treatment with TNF $\alpha$ led to a loss of claudin- 1 signal (green), in accordance with our earlier observations. ML-7 prevented the TNF $\alpha$-induced changes since claudin- 1 was detected as fine paracellular lines comparable to the controls. The paracellular signal of claudin-3 (green, Figure 7B) appeared to be mitigated compared to claudin- 1 after treatment with the cytokine, while an increased intracellular signal was also observed. Furthermore, after TNF $\alpha$-treatment, the occludin signal (red) appeared rather weak. Both can be partly prevented by ML-7, as claudin-3 and occludin were detected as fine, paracellular lines equivalent to the controls.

\subsection{Recovery Experiment}

Because TNF $\alpha$ has apoptotic potential $[29,30]$, we performed further experiments to see whether IPEC-J2 cells can recover from incubation with the cytokine. Therefore, a medium exchange was carried out after $48 \mathrm{~h}$, and cells were further incubated with or without TNF $\alpha$. As shown in Figure 8A, cells with TNF $\alpha$ removal seem to recover from $48 \mathrm{~h}$ incubation with TNF $\alpha$, since the TEER values showed a strong tendency to increase again, while the cells treated without cytokine removal decreased further on. However, the increase in TEER from cells with TNF $\alpha$ removal was not sufficient enough for a significant difference to the cells without the removal of the cytokine, but was close to being statistically significant (one-way ANOVA: F $(2,26)=6.64, p=0.0047, n=7-13$; TNF $\alpha$ w /o Recovery: $77.36 \pm 11.41 \%$; TNF $\alpha \mathrm{w} /$ Recovery: $115.88 \pm 15.65 \% ; p=0.076$ ). The control groups showed a strong significant difference compared to the cells treated with TNF $\alpha$ for $96 \mathrm{~h}$, (ctrl: $129.75 \pm 7.82 \%$; TNF $\alpha \mathrm{w}$ /o Recovery: $77.36 \pm 11.40 ; p=0.0036$ ). To analyze the effects a recovery period from TNF $\alpha$ might have on the changes in TJ proteins and TNFR-1, Western blot analysis and confocal laser scanning immunofluorescence microscopy were performed subsequently. A recovery period of $48 \mathrm{~h}$ after incubation with the cytokine led to a marked increase in claudin-1 expression in IPEC-J2 cells (one-way ANOVA: $\mathrm{F}(2,6)=61.35$, $p=0.0001, n=3$; TNF $\alpha$ w /o Recovery: $38.11 \pm 2.34 \%$; TNF $\alpha$ w / Recovery: $63.20 \pm 6.47 \%$; $p=0.01$; Figure $8 \mathrm{~B}, \mathrm{C})$. Though, there was still a significant difference between controls and cells treated with $\mathrm{TNF} \alpha$ recovery (Ctrl: $100 \%$; TNF $\alpha \mathrm{w} /$ Recovery: $63.20 \pm 6.47 \%$; $p=0.002)$. Densitometric analysis of claudin-3 also revealed a rise after the removal of the cytokine, yet not to the same extent as claudin-1 (one-way ANOVA: $\mathrm{F}(2,6)=5.84, p=0.039$, $n=3 ; \mathrm{TNF} \alpha \mathrm{w}$ /o Recovery: $69.77 \pm 8.10 \%$; TNF $\alpha \mathrm{w} /$ Recovery: $95.08 \pm 8.33 \% ; p=0.08$ ). For occludin expression, the recovery period led to a strong increase compared to the cells treated with TNF $\alpha$ for $96 \mathrm{~h}$ (one-way ANOVA: $\mathrm{F}(2,6)=16.24, p=0.004, n=3$; TNF $\alpha \mathrm{w} / \mathrm{o}$ Recovery: $58.32 \pm 8.40 \%$; TNF $\alpha$ w / Recovery: $81.70 \pm 3.18 \% ; p=0.04)$. The increased expression of TNFR- 1 due to TNF $\alpha$ incubation was not affected by the recovery period (Kruskal-Wallis test: $\mathrm{H}(2)=4.78, p=0.09, n=3$ ).

Moreover, confocal laser scanning immunofluorescence microscopy revealed that the paracellular TJ strands seemed to reconstitute after a recovery period of $48 \mathrm{~h}$, as the claudin-1 signal appeared to be integrated again in the lateral membrane after a loss due to TNF $\alpha$ incubation (Figure 9A). Forty-eight hours after the removal of the cytokine, the signal for claudin-3 appeared to be as strong as detected in controls. The occludin signal also appeared to recover from the incubation with $\operatorname{TNF} \alpha$, but still showed a weaker signal compared to the controls, which was also reflected by a weaker yellow signal in the merged pictures (Figure 9B). Furthermore, a marked internalization of claudin-3 to sub-junctional compartments was observed when cells were incubated with TNF $\alpha$ for $96 \mathrm{~h}$. 


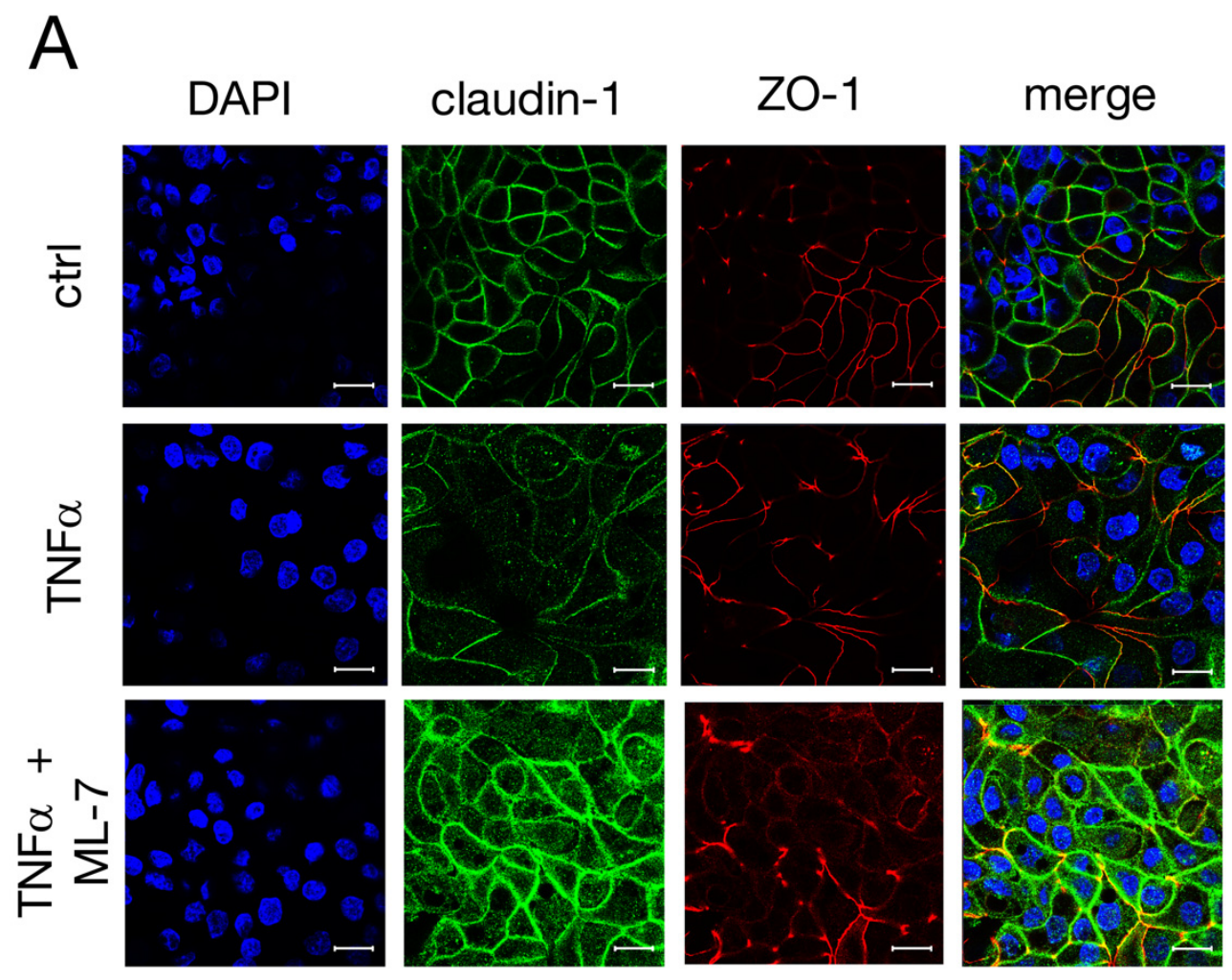

B

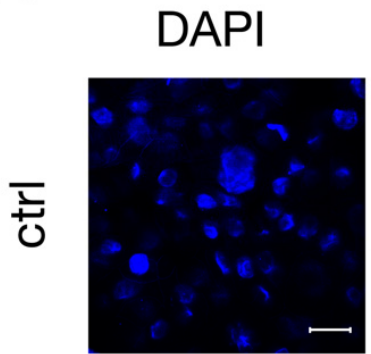

claudin-3
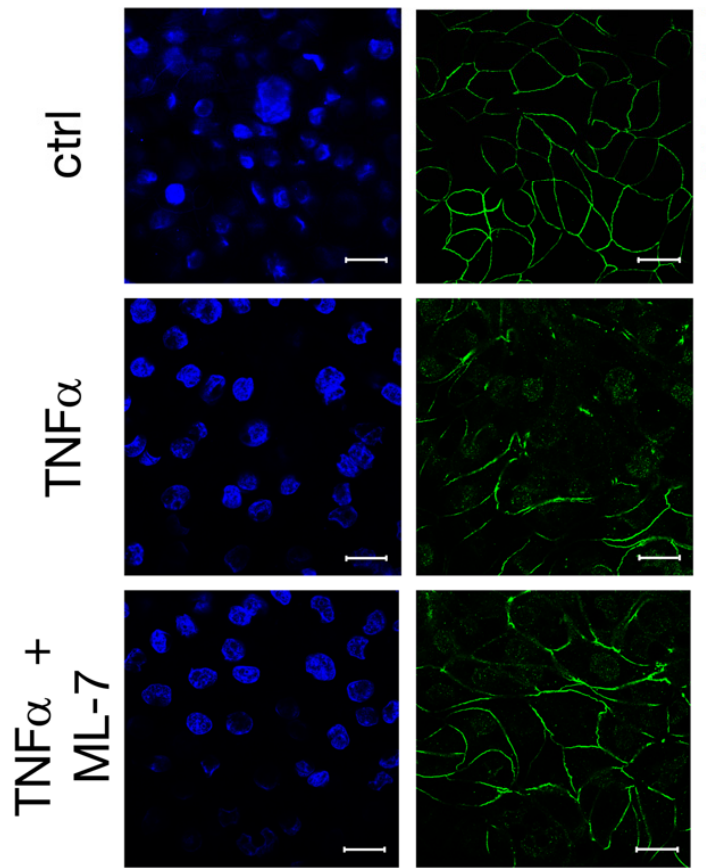
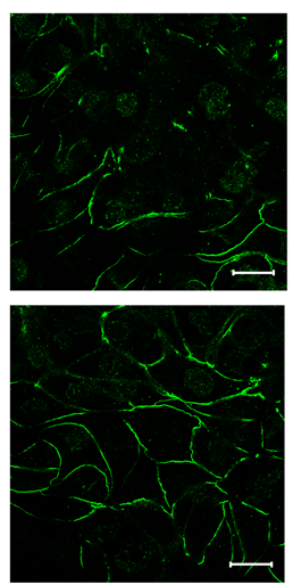

occludin
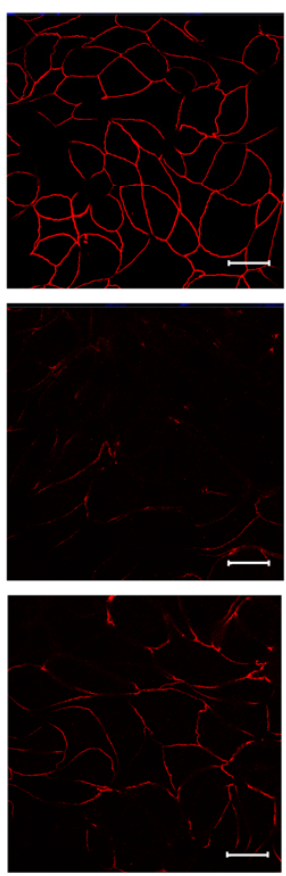

merge
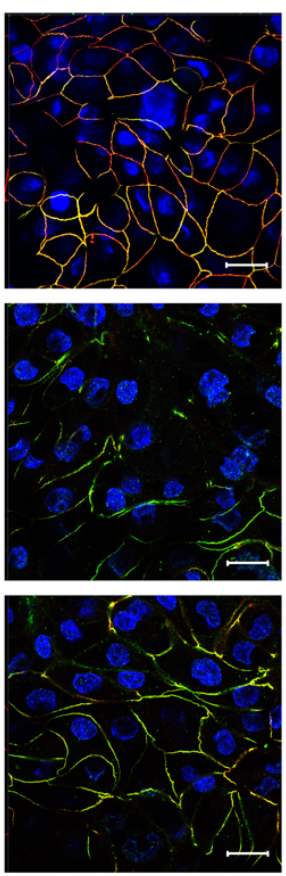

Figure 7. Confocal laser scanning immunofluorescence microscopy of (A) claudin-1 (green) and ZO-1 (red), as well as (B) claudin-3 (green) and occludin (red), nuclei were stained in blue (DAPI). IPEC-J2 monolayers were treated for $48 \mathrm{~h}$ with TNF $\alpha$ in the presence or absence of the specific MLCK blocker ML-7. (B) The yellow signal in the merged pictures represents the colocalization of claudin-3 and occludin (scale bar: $20 \mu \mathrm{m} ; n=4$; representative images). 
A

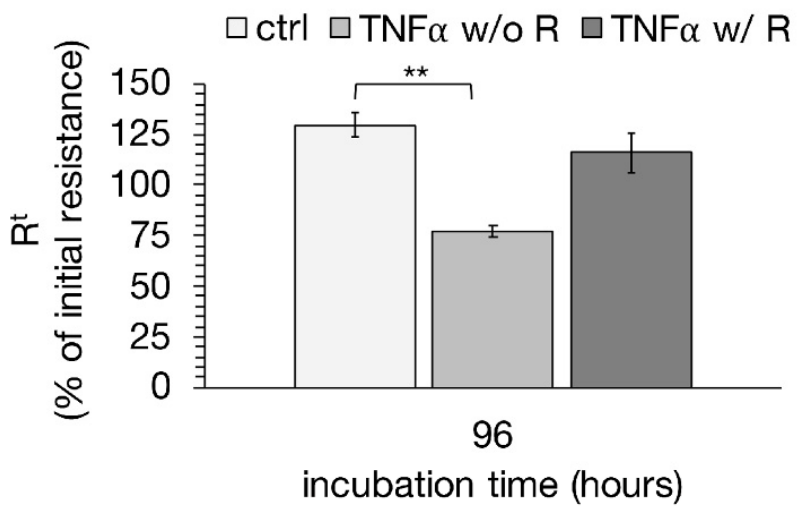

C

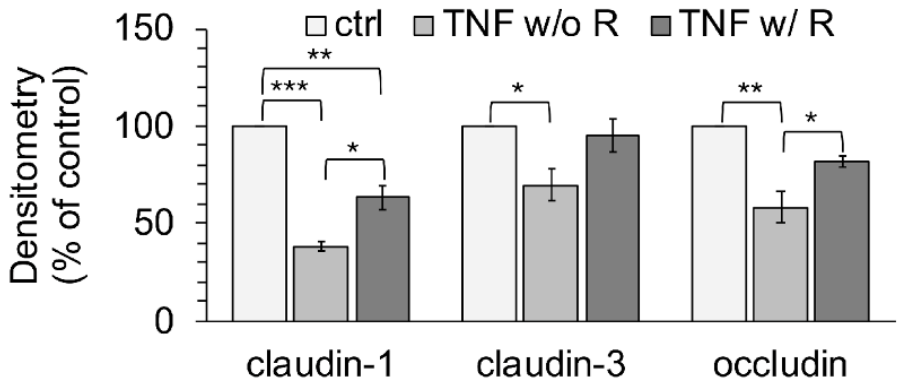

$\mathrm{B}$

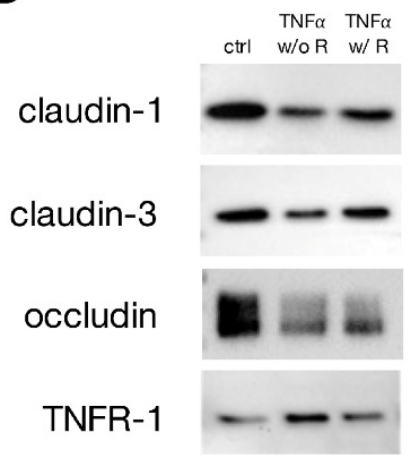

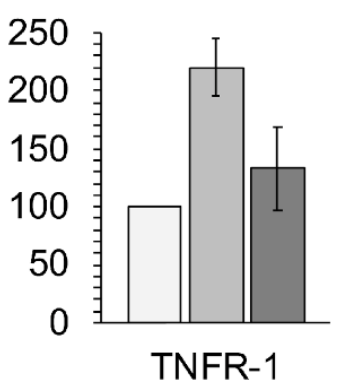

Figure 8. After IPEC-J2 cells were treated for $48 \mathrm{~h}$ with $1000 \mathrm{U} / \mathrm{mL} \mathrm{TNF} \alpha$, a medium exchange was carried out and cells were either further incubated with the cytokine (TNF $\alpha$ without recovery; $\mathrm{w} / \mathrm{o} \mathrm{R}$ ) or incubated with normal medium without TNF $\alpha$ (TNF $\alpha$ with recovery; w/R) for another $48 \mathrm{~h}$. (A) TEER values of groups treated with TNF $\alpha$ removal were compared to cells treated without removal of the cytokine, respectively (one-way ANOVA, ${ }^{* *} p<0.01 ; n=7-13$ ). (B) Representative Western blot bands and (C) Densitometry of IPEC-J2 cells with or without recovery after $48 \mathrm{~h}$ incubation with TNF $\alpha$ revealed an increase in claudin-1 and occludin after removal of the cytokine, while claudin-3 expression did not show significant changes. The expression level of TNFR- 1 also did not seem to be affected by TNF $\alpha$ removal. The shown data are presented as mean \pm SEM (one-way ANOVA, ${ }^{*} p<0.05,{ }^{* *} p<0.01,{ }^{* * *} p<0.001 ; n=3$ ).

\subsection{ApoTox-Glo Assay}

In addition to the recovery experiments, an ApoTox-Glo assay was performed and the apoptotic potential of TNF $\alpha$ was further analyzed to ensure that the changes in barrier function are not due to the induction of apoptosis by the cytokine. Despite all this, neither the apoptotic or the cytotoxic rate nor the viability of IPEC-J2 cells was significantly changed after treatment with $1000 \mathrm{U} / \mathrm{mL} \mathrm{TNF} \alpha$ for $48 \mathrm{~h}$. Hence, apoptosis could be eliminated as a cause for the decrease in transepithelial resistance in IPEC-J2 cells (data not shown). 
A

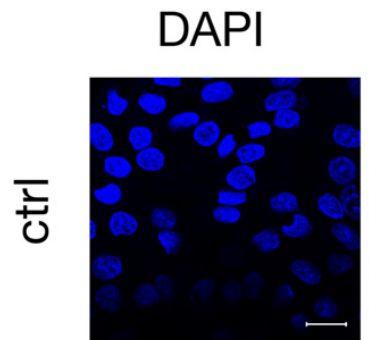

claudin-1
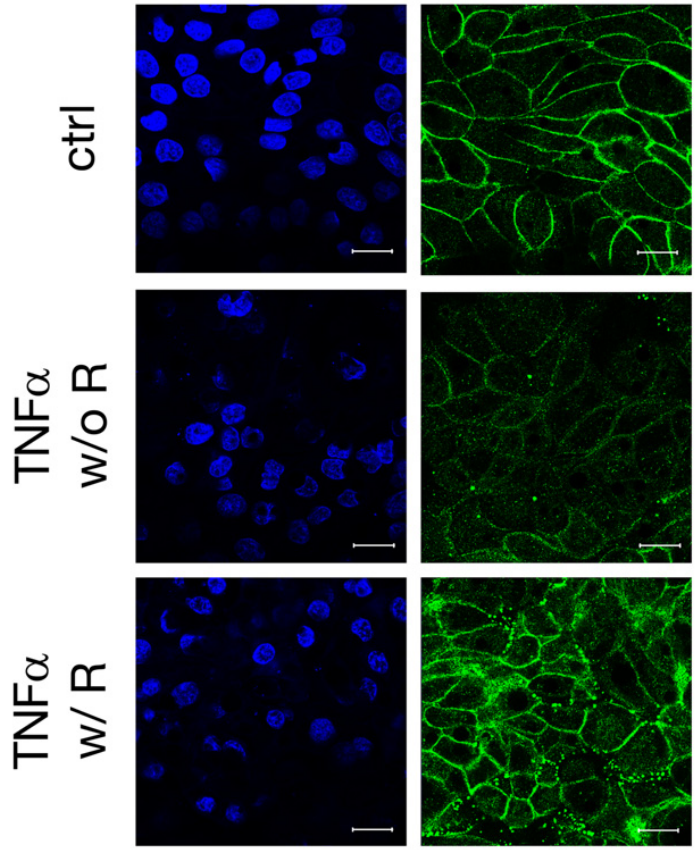

B
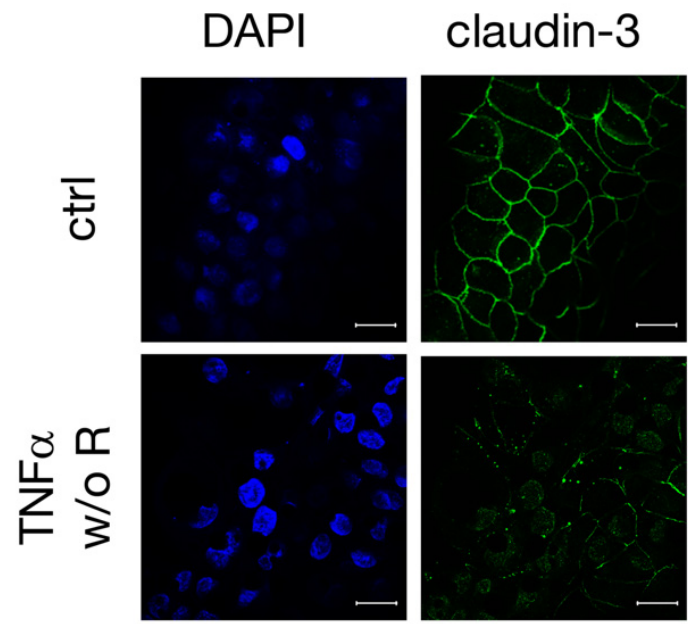

occludin
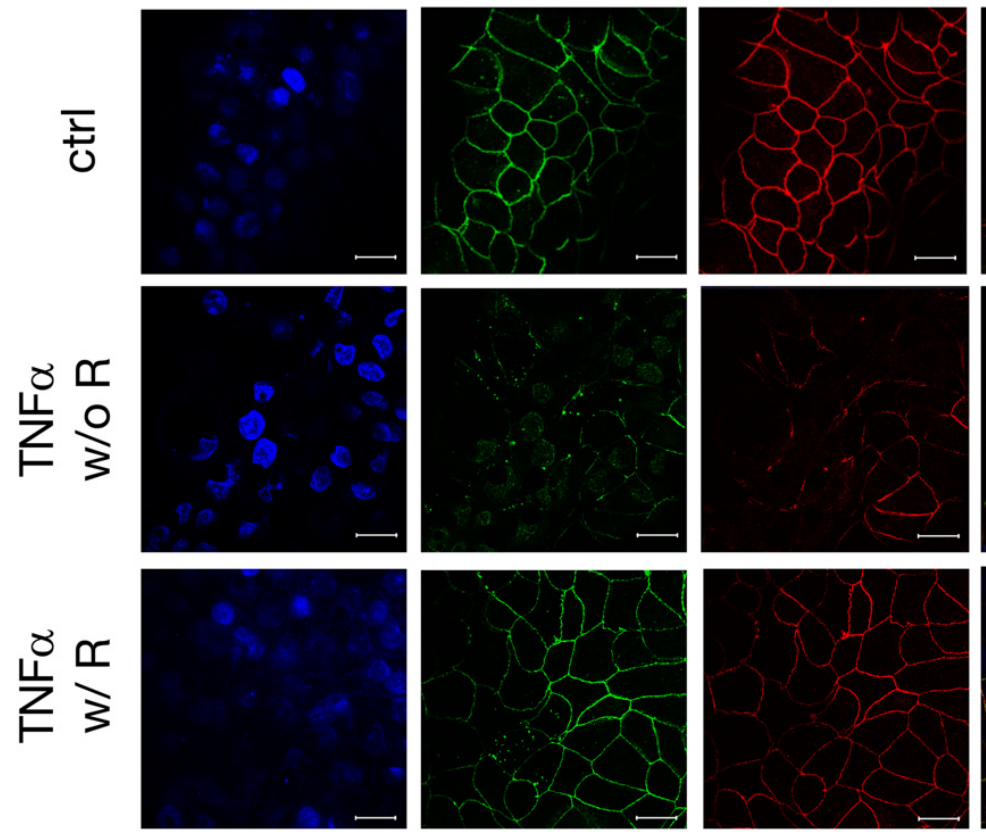

merge
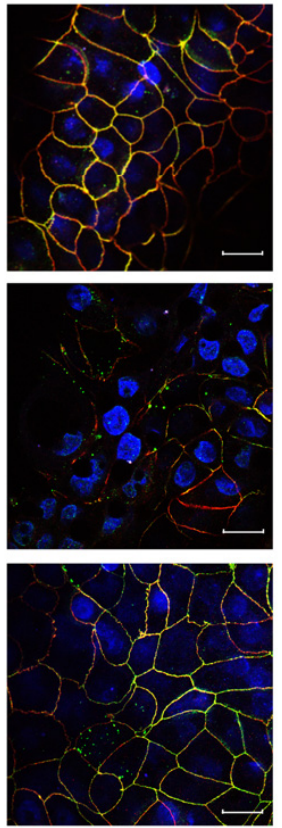

Figure 9. To analyze whether a recovery period from $\mathrm{TNF} \alpha$ may have effects on the localization of changed TJ proteins due to treatment with the cytokine, confocal laser scanning immunofluorescence microscopy was performed subsequent to experiments. (A) Claudin-1 (green) and ZO-1 (red), and (B) claudin-3 (green) and occludin (red) were stained. Nuclei were stained in blue (DAPI). The yellow signal in the merged pictures constitutes a colocalization of the stained TJ proteins (scale bar: $20 \mu \mathrm{m}$; $n=3$; representative pictures). 


\section{Discussion}

The intestinal mucosa provides one of the most important barriers to the outside environment, and an intact barrier is maintained by TJs linking adjacent epithelial cells and the immune system [31,32]. One of the main cytokines mediating between immune cells and barrier regulation is $\mathrm{TNF} \alpha$, a pro-inflammatory cytokine produced mainly by activated macrophages, monocytes and T-cells [33]. An increased, persistent production of $\mathrm{TNF} \alpha$ has been shown to cause mucosal inflammation, leading to the destruction of the intestinal barrier with increased permeability due to the reduced function of the TJs, but also to the apoptosis of intestinal epithelial cells [34].

In our current work, we analyzed the effects of TNF $\alpha$ on the intestinal epithelial barrier function of the non-transformed porcine intestinal epithelial cell line IPEC-J2. Although this cell line has been described as a suitable in vitro model so far [19], the central effect of $\mathrm{TNF} \alpha$ on the barrier function of IPEC-J2, in particular on the expression and localization of TJ proteins, has not been analyzed in detail yet.

As already assumed, the use of TNF $\alpha$ showed a highly significant decrease in TEER, as well as an elevation in paracellular permeability to [ $\left.{ }^{3} \mathrm{H}\right]-\mathrm{D}-\mathrm{Mannitol}$, both representing epithelial barrier function. To analyze this barrier-weakening effect more precisely, immunoblots and confocal laser scanning immunofluorescence microscopy of TJ proteins including claudin- $1,-3,-4,-7$, occludin and ZO-1 were subsequently carried out. In our study, strong yet differential effects of the cytokine on different TJ proteins were observed. Hence, the participation of the sealing TJ proteins claudin- 1 , as well as claudin- 3 and occludin, on the disruption of epithelial barrier function could be shown, as the decrease in these integral membrane proteins after incubation with TNF $\alpha$ was in accordance with functional changes. In addition, not only a marked reduction in protein expression could be shown, but also a disruption of those TJ proteins, as the signal of claudin- $-1,-3$ and occludin was either much reduced, disintegrated or located more intracellularly than in the cells treated without the cytokine.

Because TNF $\alpha$ can bind two specific receptors, namely TNFR-1 and TNFR-2, we aimed to analyze if the observed changes are linked to the altered density of these receptors. Hence, we were able to detect a dose-dependent increase in TNFR-1 due to the incubation with $\mathrm{TNF} \alpha$, while TNFR- 2 remained unchanged. One reason for this might be the expression of TNFR-1 in most tissues, while TNFR-2 appears to be found mostly in the lymphoid system. TNFR-1 is also the key signaling receptor for $\mathrm{TNF} \alpha$, as it is activated by both soluble and membrane-bound TNF $\alpha$ and mediates the signaling of apoptosis and inflammation [35,36]. Furthermore, TNFR-2 can only be fully activated by membrane-bound but not soluble $\mathrm{TNF} \alpha[29]$.

To exclude the possibility that the observed changes are associated with an activation of apoptosis by TNF $\alpha[29,30]$, we performed recovery experiments as well as an ApoToxGlo assay. As the ApoTox-Glo assay did not show any significant changes in caspase-3/-7 activity, and the previously mentioned alterations in TEER and TJ proteins were reversible after the removal of the cytokine, we were able to eliminate apoptosis as a reason for the observed changes.

Because the disruption of TJ proteins has been explained to be in accordance with an increased expression of MLCK [13-15,37], we analyzed if the TNF $\alpha$-induced effects could be prevented by ML-7, a specific MLCK blocker [38,39]. TNF $\alpha$ can operate as an activator for MLCK, in turn leading to the increased permeability of the paracellular barrier [18]. Regarding a changed TJ barrier function, different routes can be involved, in particular the low-capacity leak and the high-capacity pore pathways [40,41]. The low-capacity leak pathway allows macromolecules to cross the TJ barrier, and is involved when TNF $\alpha$ stimulates MLCK [18]. To understand what role MLCK plays in our observed changes in TJ composition, cells were incubated with TNF $\alpha$ in the presence or absence of ML-7. TEER was recorded and the protein expression and distribution of claudin-1, -3, occludin and TNFR-1 were analyzed, indicating MLCK as the major pathway component of TNF $\alpha$ signaling. 
Incubation with TNF $\alpha$ in the presence of the specific MLCK blocker ML-7 prevented the decrease in TEER and claudin-3 expression. However, in our experiments, occludin expression was not significantly altered. Whether the effects of MLCK are related to a role for myosin transport of the affected proteins, or if MLCK might have other, e.g., structural roles $[42,43]$, could not be addressed within the scope of the current study in more detail, but might be of interest for ongoing research. However, as a possible major MLCK substrate, myosin light chain II (MLC-2) has been shown to mediate alterations of paracellular permeability in gastrointestinal disorders [14].

In our current study, the pharmacological perturbation of MLCK was performed by the small molecule inhibitor ML-7. Although additional results such as (i) MLCK knockdown during TNF $\alpha$ treatment and (ii) MLCK overexpression in the absence of TNF $\alpha$ might even have strengthened the study, the blocking experiment has proven reliable for a convincing conclusion on the role of MLCK. Other additional mechanisms and signaling events might be still involved, though.

In a publication from Xiao et al., IPEC-J2 cells were stimulated with TNF $\alpha$ to analyze whether TGF- $\beta 1$ may have protective effects. After TNF $\alpha$ challenge, a reduction in occludin and ZO-1 of IPEC-J2 monolayers was observed, while the TJ protein claudin-1 remained unaffected [44]. This is in contrast with the alteration of TJ proteins in our work, as in our experiments, the TJ proteins claudin-1, -3 and occludin were markedly reduced after incubation with TNF $\alpha$. Thus, our findings demonstrate once again that the cell line IPEC-J2, cultured under species-specific conditions using porcine serum instead of conventional serum [20], shows an improved model for the analysis of porcine jejunal epithelium, as the changes in TJ composition are more commensurate to those in other models after TNF $\alpha$ challenge $[45,46]$.

An effect of TNF $\alpha$ not only on sealing but also on pore-forming tight junction proteins has been described previously [11]. In different models [47-49], incubation with TNF $\alpha$ led to a significant increase in claudin-2, a paracellular channel for small cations and water [50]. Due to the lack of IPEC-J2 regarding the expression of pore-forming TJ proteins [20], an examination of the effect on these particular proteins could not be performed in our current approach. However, with a lack of claudin-2 expression, the TJ expression pattern of IPEC-J2 appears to be very close to Peyer's patches follicle-associated epithelium, therefore representing the main relevant epithelium involved in immune surveillance in the intestine [51,52]. Currently, many studies demonstrate the susceptibility and reliability of the non-malignant porcine epithelial cell line IPEC-J2 regarding a wide variety of mechanisms in native tissue of different species in vitro $[19,53]$.

\section{Material and Methods}

\subsection{Cell Culturing and TNF $\alpha$ Treatment}

Confluent monolayers of the porcine jejunal cell line IPEC-J2 (DSMZ, Braunschweig, Germany) were grown in $25 \mathrm{~cm}^{2}$ culture flasks in Dulbecco's MEM/Ham's F-12 (Biochrom, Berlin, Germany) containing $3.15 \mathrm{~g} / \mathrm{L}$ glucose, $2 \mathrm{mM}$ stable glutamine, $10 \%$ porcine serum (Sigma Aldrich, Munich, Germany) and 1\% penicillin/streptomycin (Sigma Aldrich, Munich, Germany). Cells were cultured at $37{ }^{\circ} \mathrm{C}$ in a humified $5 \% \mathrm{CO}_{2}$ atmosphere. The medium was changed every $2-3$ days and cells were split once a week at a ratio of 1:3. For electrophysiological measurements, cells were seeded at a density of $2 \times 10^{5}$ cells $/ \mathrm{mL}$ on semipermeable cell culture inserts with a diameter of $12 \mathrm{~mm}$ and a pore size of $0.45 \mu \mathrm{m}$ (Millipore, Darmstadt, Germany) and placed into multi-well plates. Routinely, $500 \mu \mathrm{L}$ of media was added to the apical compartment, and the basolateral compartment was filled with $1 \mathrm{~mL}$ of media to guarantee an equal hydrostatic pressure, as specified by the manufacturer. Experiments were performed after cells reached similar $\mathrm{R}^{\mathrm{t}}$ values ( 14 days) to ensure a functional barrier. Therefore, recombinant human TNF $\alpha$ (peprotech, Hamburg, Germany) was added in various concentrations $(50,100,500,1000$ and $5000 \mathrm{U} / \mathrm{mL}$ ) to the basolateral side of the cell culture inserts, and transepithelial resistance was monitored for $48 \mathrm{~h}$. The cells were further processed and used for immunoblotting and immunohisto- 
chemistry, as described below. Resistance values were corrected with the blank values of the filters and the media used in the experiments. Only cells with passages between 7 and 12 were used for experimental purposes.

\subsection{TEER and Flux Measurements}

Transepithelial electrical resistance (TEER) measurements, presenting the epithelial barrier function, were assessed by using a chopstick electrode and an Epithelial Volt/Ohm Meter (EVOM, World Precision Instruments, Sarasota, FL, USA). Permeability studies were carried out using $\left[{ }^{3} \mathrm{H}\right]$-D-Mannitol to examine the unidirectional paracellular tracer flux from the apical to the basolateral side of the cell filters. Cells were seeded on semipermeable cell culture inserts as described previously. A total of $0.18 \mu \mathrm{Ci}$ of $\left[{ }^{3} \mathrm{H}\right]$-D-Mannitol (PerkinElmer, Waltham, MA, USA) was added to the apical side of the filters, and samples of $50 \mu \mathrm{L}$ were taken directly and $48 \mathrm{~h}$ after addition of the tracer. Subsequently, the specific activity of the tracer was calculated using Equation (1).

$$
\text { specific activity }[\mathrm{nmol}]=\frac{\text { mean }\left(\text { counts }_{\text {donor side }}\right)}{\text { concentration }_{\text {donor side }} \times \text { volume }_{\text {donor side }}}
$$

For permeability measurements, samples of $300 \mu \mathrm{L}$ were taken every $24 \mathrm{~h}$ during the incubation with the cytokine from the basolateral side, resulting in two flux periods. The removed media were replaced with fresh media containing the corresponding TNF $\alpha$ concentration. Following the sampling, Aquasafe 300plus liquid scintillation cocktail (Zinsser Analytic, Frankfurt, Germany) was added and each sample was examined using TriCarb 4910TR liquid scintillation counter (PerkinElmer, Waltham, MA, USA). By using Equation (2), the resulting paracellular flux was calculated.

$$
\mathrm{J}\left[\mathrm{nmol} \times \mathrm{cm}^{-2} \times \mathrm{h}^{-1}\right]=\frac{\text { counts }_{\mathrm{t}} \times \frac{\mathrm{V}_{\text {chamber }}}{\mathrm{V}_{\text {sample }}}-\text { counts }_{\mathrm{t}-1} \times \frac{\mathrm{V}_{\text {chamber }}-\mathrm{V}_{\text {dilution }}}{\mathrm{V}_{\text {sample }}}}{\text { specific activity } \times \text { area } \times \text { time }}
$$

\subsection{Protein Extraction and Quantification}

After incubation of the cells with TNF $\alpha$, IPEC-J2 monolayers were washed in PBS with calcium and magnesium and lysed in RIPA buffer, containing $25 \mu \mathrm{M}$ HEPES pH 7.6, $25 \mu \mathrm{M} \mathrm{NaF}, 2 \mu \mathrm{M}$ EDTA, 1\% Sodium Dodecyl Sulfate (10\%), H2O and enzymatic protease inhibitors (Complete EDTA-free, Boehringer, Mannheim, Germany). Cells were then scraped off the permeable supports and the suspension was transferred into Eppendorf tubes. Samples were homogenized after incubation on ice for $30 \mathrm{~min}$. Protein quantification was performed by using Bio-Rad DC Protein Assay (Bio-Rad Laboratories GmbH, Munich, Germany) as prescribed by the manufacturer. For the detection, EnSpire Multimode Plate Reader (Perkin Elmer, Waltham, MA, USA) was used.

\subsection{Immunoblotting and Densitometry}

Western blot analysis was performed to identify the TJ protein expression after TNF $\alpha$ treatment. Protein $(20 \mu \mathrm{g})$ and Laemmli buffer (Bio-Rad Laboratories $\mathrm{GmbH}$, Munich, Germany) were mixed and loaded onto 10\% TGX Stain-Free FastCast gels (Bio-Rad Laboratories $\mathrm{GmbH}$, Munich, Germany). Electrophoresis was carried out for $60 \mathrm{~min}$ at $150 \mathrm{~V}$. Subsequently, samples were transferred onto a PVDF membrane for $90 \mathrm{~min}$ at $100 \mathrm{~V}$ and blocked for $60 \mathrm{~min}$ in 5\% milk (in Tris-buffered saline with $0.1 \%$ Tween 20). Membranes were then incubated with specific antibodies raised against TJ proteins (all from Thermo Fisher Scientific) claudin-1 (cat. \#51-9000), -3 (cat. \#34-1700), -4 (cat. \#32-9400), -7 (cat. \#34-9100), occludin (cat. \#33-1500) and ZO-1 (cat. \#33-9100) following the manufacturer's instructions at $4{ }^{\circ} \mathrm{C}$ overnight, respectively. To bind the primary antibodies, horseradishperoxidase-conjugated goat anti-mouse or goat anti-rabbit antibodies were used for $1 \mathrm{~h}$ at room temperature. Specificity was shown in detail previously $[19,51,52]$. For visualization of the protein bands, Clarity Western ECL Blotting Substrate (Bio-Rad Laboratories GmbH, 
Munich, Germany) was used after the total protein amount was detected with the ChemiDoc MP Luminescence imager (ChemiDoc MP, Munich, Germany). Later, the density of the specific bands was quantified and analyzed using the imager-associated software Image Lab. For densitometry, bands were normalized on total protein amount and compared to the control groups, respectively.

\subsection{Immunohistochemistry}

Confocal laser scanning immunofluorescence microscopy was performed for the detection and localization of TJ proteins after TNF $\alpha$ treatment. Therefore, cells were washed twice with PBS and fixated in ice-cold methanol for $10 \mathrm{~min}$ at $-20^{\circ} \mathrm{C}$. Permeabilization was carried out using Triton X-100 for $10 \mathrm{~min}$ at room temperature. Cells were then blocked for $60 \mathrm{~min}$ in PBS containing 1\% bovine serum albumin and 5\% goat serum and subsequently incubated with primary antibodies raised against claudin-1, -3 , occludin and ZO-1 for $60 \mathrm{~min}$ at $37^{\circ} \mathrm{C}$ (Thermo Fisher Scientific; claudin-1 (cat. \#51-9000), -3 (cat. \#34-1700), occludin (cat. \#33-1500) and ZO-1 (cat. \#33-9100)). Again, cells were washed with PBS and then incubated with secondary goat anti-rabbit Alexa Fluor-488 (1:1000, Thermo Fisher Scientific, cat. \#A-11008) or goat anti-mouse Alexa Fluor-594 (cat. \#A11005) for $60 \mathrm{~min}$ at $37^{\circ} \mathrm{C}$. Nuclei were stained with DAPI (1:2000) for $5 \mathrm{~min}$ at room temperature. Following this, filters were mounted with ProTaqs Mount Fluor (Biocyc, Luckenwalde, Germany) and slides were analyzed by using Zeiss 710 confocal microscope (Zeiss, Oberkochen, Germany).

4.6. Investigation of Dose-Dependent Changes in the Expression Level and Localization of Tumor Necrosis Factor Receptor 1 or 2 after Treatment with TNFa

To examine whether the treatment with TNF $\alpha$ affects the expression level of tumor necrosis factor receptors 1 and 2 (TNFR-1, TNFR-2) in IPEC-J2 cells, Western blot analysis was carried out as mentioned above. Membranes were incubated with rabbit polyclonal antibodies raised against TNFR-1 (abcam, cat. \#ab1939) and TNFR-2 (antibodies-online, cat. \#ABIN2789622). After detection, specific bands were normalized on total protein amount and analyzed compared to the untreated groups, respectively. Moreover, immunohistochemistry of IPEC-J2 cells, treated with rising TNF $\alpha$ concentrations, was performed for examination of expression level and localization of TNFR-1. Therefore, a staining using specific antibodies raised against TNFR-1 together with a marker for the basolateral membrane, namely Integrin beta-1 (ITG $\beta 1$; Thermo Fisher, Rockford, IL, USA), was carried out as mentioned above. To analyze the location of TNFR-1 in more detail, Z-stacks were performed additionally.

\subsection{Specific Myosin Light Chain Kinase (MLCK) Blocker in TNFa-Induced Changes in Epithelial} Barrier Function

For a more detailed characterization of the signaling in TNF $\alpha$-induced barrier changes, ML-7 (Sigma Aldrich, Munich, Germany), a specific blocker against MLCK, was used. Therefore, IPEC-J2 cells were incubated with TNF $\alpha(1000 \mathrm{U} / \mathrm{mL})$ in the presence or absence of ML-7 $(10 \mu \mathrm{M})$. Stock solutions of ML-7, dissolved in dimethyl sulfoxide (DMSO; Sigma Aldrich, Munich, Germany), were diluted in medium and added simultaneously with $\mathrm{TNF} \alpha$ to the apical and basolateral compartment of the cell filters. Respectively, $0.1 \%$ of DMSO was added to controls as well as to cell filters incubated with TNF $\alpha$ without ML-7, to exclude a DMSO-dependent effect on IPEC-J2 cells. TEER measurements were carried out before addition and after $48 \mathrm{~h}$. Subsequent to TEER measurements, cells were either fixated for immunohistochemistry or proteins were extracted and further processed for immunoblotting, analyzing localization and expression of TJ proteins after experiments with or without ML-7.

\subsection{Recovery Experiments in IPEC-J2 after Removal of TNF $\alpha$}

Because TNF $\alpha$ has been described to have apoptotic potential, we wanted to investigate if the IPEC-J2 cells can recover from the TEER decrease after a TNF $\alpha$-challenge. 
Therefore, cells were incubated with $1000 \mathrm{U} / \mathrm{mL} \mathrm{TNF} \alpha$ for $48 \mathrm{~h}$ as described above. Subsequently, a medium exchange was carried out and fresh media without TNF $\alpha$ were added to the cells that were treated with the cytokine before. Following TEER measurements, possible alterations of TJ proteins were examined using Western blot technique or immunohistochemistry as described above.

\subsection{ApoTox-Glo Assay}

IPEC-J2 cells were seeded as triplicates at a density of $2 \times 10^{5}$ cells $/ \mathrm{mL}$ on PET cell culture inserts of a 24-well Transwell system with $6.5 \mathrm{~mm}$ membrane diameter and a $0.4 \mu \mathrm{m}$ pore size (Costar, Corning Incorporated, Kennebunk, ME, USA). After a cultivation period of 14 to 16 days, cells were treated with TNF $\alpha(1000 \mathrm{U} / \mathrm{mL})$ and further incubated for $48 \mathrm{~h}$. To measure the viability, cytotoxicity and apoptosis of the IPEC-J2 cells, the ApoTox-Glo ${ }^{\mathrm{TM}}$ Triplex Assay (Promega GmbH, Walldorf, Germany) was carried out according to the manufacturer's specifications. After the incubation period with TNF $\alpha$, the viability/cytotoxicity reagent, containing both the bis-AAF-R110 substrate and GF-AFC substrate, was added to each well and mixed for $30 \mathrm{~s}$ on an orbital shaker. After an incubation of $30 \mathrm{~min}$ at $37^{\circ} \mathrm{C}$, the fluorescence was measured at $400 \mathrm{EX} / 505 \mathrm{EM}$ for viability and $485 \mathrm{EX} / 520 \mathrm{EM}$ for cytotoxicity. Following this, the apoptosis reagent, containing the Caspase-Glo 3/7 substrate, was added to each well, mixed gently and incubated for another $30 \mathrm{~min}$ at constant room temperature. Luminescence was measured to detect cell apoptosis. All measurements were carried out using EnSpire Multimode Plate Reader (Perkin Elmer, Waltham, MA, USA).

\subsection{Statistical Analysis}

Data are always expressed in means and standard error of the mean (SEM). $\mathrm{N}$ represents the number of cell culture inserts used unless stated otherwise. For TEER measurements, statistical analysis was performed using one-way ANOVA and Dunnett's test for the correction of multiple testing. For comparison between two groups, unpaired Student's $t$-test was used. Statistical analysis for densitometry of Western blots was performed with one-way ANOVA for normally distributed data and with Kruskal-Wallis test for non-normally distributed data. For the signaling experiments, Tukey-Kramer method was used as post hoc test for pairwise comparisons. Values of $p<0.05$ were considered to be statistically significant, being presented as ${ }^{*} p<0.05,{ }^{* *} p<0.01$ and ${ }^{* *} p<0.001$.

\section{Conclusions}

Employing the non-transformed intestinal epithelial cell line IPEC-J2, our study demonstrates, for the first time, that the exponential nature of barrier impairment by $\mathrm{TNF} \alpha$ in porcine intestinal inflammatory processes can be explained by the finding that its own receptor, TNFR-1, is upregulated by TNF $\alpha$ itself.

Author Contributions: Conceptualization, S.A. and L.D.; methodology, S.A., L.D., V.C. and A.G.M.; investigation, L.D. and V.C.; writing-original draft preparation, L.D. and S.A.; writing-review and editing, L.D., S.A., A.G.M. and V.C.; supervision, S.A.; funding acquisition, S.A. All authors have read and agreed to the published version of the manuscript.

Funding: This work was supported by a grant of the German Research Foundation, DFG grant no. AM141/11-2. The publication of this article was funded by Freie Universität Berlin.

Institutional Review Board Statement: Not applicable.

Informed Consent Statement: Not applicable.

Data Availability Statement: Data are contained within the article. The datasets analyzed during the current study are available from the corresponding author upon reasonable request.

Acknowledgments: We thank Katharina Söllig, Susanne Trappe and Martin Grunau for excellent technical assistance. 
Conflicts of Interest: The authors declare no competing or financial interests.

\section{References}

1. Tsukita, S.; Furuse, M.; Itoh, M. Multifunctional strands in tight junctions. Nat. Rev. Mol. Cell Biol. 2001, 2, 285-293. [CrossRef]

2. Martin-Padura, I.; Lostaglio, S.; Schneemann, M.; Williams, L.; Romano, M.; Fruscella, P.; Panzeri, C.; Stoppacciaro, A.; Ruco, L.; Villa, A.; et al. Junctional adhesion molecule, a novel member of the immunoglobulin superfamily that distributes at intercellular junctions and modulates monocyte transmigration. J. Cell Biol. 1998, 142, 117-127. [CrossRef] [PubMed]

3. Mineta, K.; Yamamoto, Y.; Yamazaki, Y.; Tanaka, H.; Tada, Y.; Saito, K.; Tamura, A.; Igarashi, M.; Endo, T.; Takeuchi, K.; et al. Predicted expansion of the claudin multigene family. FEBS Lett. 2011, 585, 606-612. [CrossRef] [PubMed]

4. Markov, A.G.; Veshnyakova, A.; Fromm, M.; Amasheh, M.; Amasheh, S. Segmental expression of claudin proteins correlates with tight junction barrier properties in rat intestine. J. Comp. Physiol. B 2010, 180, 591-598. [CrossRef] [PubMed]

5. Schulzke, J.D.; Ploeger, S.; Amasheh, M.; Fromm, A.; Zeissig, S.; Troeger, H.; Richter, J.; Bojarski, C.; Schumann, M.; Fromm, M. Epithelial tight junctions in intestinal inflammation. Ann. N. Y. Acad. Sci. 2009, 1165, 294-300. [CrossRef] [PubMed]

6. Sartor, R.B. Mechanisms of disease: Pathogenesis of Crohn's disease and ulcerative colitis. Nat. Clin. Pract. Gastroenterol. Hepatol. 2006, 3, 390-407. [CrossRef] [PubMed]

7. Van Deventer, S.J. Tumour necrosis factor and Crohn's disease. Gut 1997, 40, 443-448. [CrossRef] [PubMed]

8. Amasheh, M.; Fromm, A.; Krug, S.M.; Amasheh, S.; Andres, S.; Zeitz, M.; Fromm, M.; Schulzke, J.D. TNFalpha-induced and berberine-antagonized tight junction barrier impairment via tyrosine kinase, Akt and NFkappaB signaling. J. Cell Sci. 2010, 123 Pt 23, 4145-4155. [CrossRef]

9. Marano, C.W.; Lewis, S.A.; Garulacan, L.A.; Soler, A.P.; Mullin, J.M. Tumor necrosis factor-alpha increases sodium and chloride conductance across the tight junction of CACO-2 BBE, a human intestinal epithelial cell line. J. Membr. Biol. 1998, 161, 263-274. [CrossRef]

10. Amasheh, M.; Grotjohann, I.; Amasheh, S.; Fromm, A.; Soderholm, J.D.; Zeitz, M.; Fromm, M.; Schulzke, J.D. Regulation of mucosal structure and barrier function in rat colon exposed to tumor necrosis factor alpha and interferon gamma in vitro: A novel model for studying the pathomechanisms of inflammatory bowel disease cytokines. Scand. J. Gastroenterol. 2009, 44, 1226-1235. [CrossRef]

11. Günzel, D.; Yu, A.S. Claudins and the modulation of tight junction permeability. Physiol. Rev. 2013, 93, 525-569. [CrossRef]

12. Marchiando, A.M.; Shen, L.; Graham, W.V.; Weber, C.R.; Schwarz, B.T.; Austin, J.R., 2nd; Raleigh, D.R.; Guan, Y.; Watson, A.J.; Montrose, M.H.; et al. Caveolin-1-dependent occludin endocytosis is required for TNF-induced tight junction regulation in vivo. J. Cell Biol. 2010, 189, 111-126. [CrossRef]

13. Cunningham, K.E.; Turner, J.R. Myosin light chain kinase: Pulling the strings of epithelial tight junction function. Ann. N. Y. Acad. Sci. 2012, 1258, 34-42. [CrossRef]

14. Jin, Y.; Blikslager, A.T. The Regulation of Intestinal Mucosal Barrier by Myosin Light Chain Kinase/Rho Kinases. Int. J. Mol. Sci. 2020, 21, 3550. [CrossRef] [PubMed]

15. Ma, T.Y.; Boivin, M.A.; Ye, D.; Pedram, A.; Said, H.M. Mechanism of TNF- $\alpha$ modulation of Caco-2 intestinal epithelial tight junction barrier: Role of myosin light-chain kinase protein expression. Am. J. Physiol. Gastrointest. Liver Physiol. 2005, 288, G422-G430. [CrossRef] [PubMed]

16. Xiong, Y.; Wang, C.; Shi, L.; Wang, L.; Zhou, Z.; Chen, D.; Wang, J.; Guo, H. Myosin Light Chain Kinase: A Potential Target for Treatment of Inflammatory Diseases. Front. Pharmacol. 2017, 23, 292. [CrossRef] [PubMed]

17. Wu, F.; Li, H.; Zhang, H.; Liao, Y.; Ren, H.; Wu, J.; Zheng, D. Phosphorylated-myosin light chain mediates the destruction of small intestinal epithelial tight junctions in mice with acute liver failure. Mol. Med. Rep. 2021, 23, 392. [CrossRef]

18. He, W.-Q.; Wang, J.; Sheng, J.-Y.; Zha, J.-M.; Graham, W.V.; Turner, J.R. Contributions of Myosin Light Chain Kinase to Regulation of Epithelial Paracellular Permeability and Mucosal Homeostasis. Int. J. Mol. Sci. 2020, 21, 993. [CrossRef]

19. Schierack, P.; Nordhoff, M.; Pollmann, M.; Weyrauch, K.D.; Amasheh, S.; Lodemann, U.; Jores, J.; Tachu, B.; Kleta, S.; Blikslager, A.; et al. Characterization of a porcine intestinal epithelial cell line for in vitro studies of microbial pathogenesis in swine. Histochem. Cell Biol. 2006, 125, 293-305. [CrossRef]

20. Zakrzewski, S.S.; Richter, J.F.; Krug, S.M.; Jebautzke, B.; Lee, I.F.; Rieger, J.; Sachtleben, M.; Bondzio, A.; Schulzke, J.D.; Fromm, M.; et al. Improved cell line IPEC-J2, characterized as a model for porcine jejunal epithelium. PLoS ONE 2013, 8, e79643. [CrossRef]

21. Swindle, M.M.; Makin, A.; Herron, A.J.; Clubb, F.J., Jr.; Frazier, K.S. Swine as models in biomedical research and toxicology testing. Vet. Pathol. 2012, 49, 344-356. [CrossRef]

22. Guilloteau, P.; Zabielski, R.; Hammon, H.M.; Metges, C.C. Nutritional programming of gastrointestinal tract development. Is the pig a good model for man? Nutr. Res. Rev. 2010, 23, 4-22. [CrossRef]

23. Poritz, L.S.; Harris, L.R., 3rd; Kelly, A.A.; Koltun, W.A. Increase in the tight junction protein claudin-1 in intestinal inflammation. Dig. Dis. Sci. 2011, 56, 2802-2809. [CrossRef] [PubMed]

24. Cui, W.; Li, L.X.; Sun, C.M.; Wen, Y.; Zhou, Y.; Dong, Y.L.; Liu, P. Tumor necrosis factor alpha increases epithelial barrier permeability by disrupting tight junctions in Caco-2 cells. Braz. J. Med. Biol. Res. 2010, 43, 330-337. [CrossRef] [PubMed]

25. Ma, T.Y.; Iwamoto, G.K.; Hoa, N.T.; Akotia, V.; Pedram, A.; Boivin, M.A.; Said, H.M. TNF-alpha-induced increase in intestinal epithelial tight junction permeability requires NF-kappa B activation. Am. J. Physiol. Gastrointest. Liver Physiol. 2004, 286, G367-G376. [CrossRef] [PubMed] 
26. Gitter, A.H.; Bendfeldt, K.; Schmitz, H.; Schulzke, J.D.; Bentzel, C.J.; Fromm, M. Epithelial barrier defects in HT-29/B6 colonic cell monolayers induced by tumor necrosis factor-alpha. Ann. N. Y. Acad. Sci. 2000, 91, 193-203.

27. Schmitz, H.; Fromm, M.; Bentzel, C.J.; Scholz, P.; Detjen, K.; Mankertz, J.; Bode, H.; Epple, H.J.; Riecken, E.O.; Schulzke, J.D. Tumor necrosis factor-alpha $(\mathrm{TNF} \alpha)$ regulates the epithelial barrier in the human intestinal cell line HT-29/B6. J. Cell Sci. 1999, 112 Pt 1, 137-146. [CrossRef]

28. Lee, J.L.; Streuli, C.H. Integrins and epithelial cell polarity. J. Cell Sci. 2014, 127 Pt 15, 3217-3225. [CrossRef]

29. Wajant, H.; Pfizenmaier, K.; Scheurich, P. Tumor necrosis factor signaling. Cell Death Differ. 2003, 10, 45-65. [CrossRef]

30. Wang, P.; Qiu, W.; Dudgeon, C.; Liu, H.; Huang, C.; Zambetti, G.P.; Yu, J.; Zhang, L. PUMA is directly activated by NF-kappaB and contributes to TNF-alpha-induced apoptosis. Cell Death Differ. 2009, 16, 1192-1202. [CrossRef]

31. Keita, A.V.; Söderholm, J.D. Barrier dysfunction and bacterial uptake in the follicle-associated epithelium of ileal Crohn's disease. Ann. N. Y. Acad. Sci. 2012, 1258, 125-134. [CrossRef] [PubMed]

32. Markov, A.G.; Falchuk, E.L.; Kruglova, N.M.; Radloff, J.; Amasheh, S. Claudin expression in follicle-associated epithelium of rat Peyer's patches defines a major restriction of the paracellular pathway. Acta Physiol. 2016, 216, 112-119. [CrossRef] [PubMed]

33. Horiuchi, T.; Mitoma, H.; Harashima, S.; Tsukamoto, H.; Shimoda, T. Transmembrane TNF-alpha: Structure, function and interaction with anti-TNF agents. Rheumatology 2010, 49, 1215-1228. [CrossRef] [PubMed]

34. Zeissig, S.; Bürgel, N.; Günzel, D.; Richter, J.; Mankertz, J.; Wahnschaffe, U.; Kroesen, A.J.; Zeitz, M.; Fromm, M.; Schulzke, J.D. Changes in expression and distribution of claudin 2, 5 and 8 lead to discontinuous tight junctions and barrier dysfunction in active Crohn's disease. Gut 2007, 56, 61-72. [CrossRef]

35. Richter, F.; Williams, S.K.; John, K.; Huber, C.; Vaslin, C.; Zanker, H.; Fairless, R.; Pichi, K.; Marhenke, S.; Vogel, A.; et al. The TNFR1 Antagonist Atrosimab Is Therapeutic in Mouse Models of Acute and Chronic Inflammation. Front. Immunol. 2021, 12, 705485. [CrossRef]

36. Fischer, R.; Kontermann, R.E.; Pfizenmaier, K. Selective Targeting of TNF Receptors as a Novel Therapeutic Approach. Front. Cell Dev. Biol. 2020, 8, 401. [CrossRef]

37. Watari, A.; Sakamoto, Y.; Hisaie, K.; Iwamoto, K.; Fueta, M.; Yagi, K.; Kondoh, M. Rebeccamycin Attenuates TNF-alpha-Induced Intestinal Epithelial Barrier Dysfunction by Inhibiting Myosin Light Chain Kinase Production. Cell Physiol. Biochem. 2017, 41, 1924-1934. [CrossRef]

38. Bain, J.; McLauchlan, H.; Elliott, M.; Cohen, P. The specificities of protein kinase inhibitors: An update. Biochem. J. 2003, 371 Pt 1, 199-204. [CrossRef]

39. Huang, C.; Zhang, Z.; Wang, L.; Liu, J.; Gong, X.; Zhang, C. ML-7 attenuates airway inflammation and remodeling via inhibiting the secretion of Th2 cytokines in mice model of asthma. Mol. Med. Rep. 2018, 17, 6293-6300. [CrossRef]

40. Weber, C.R. Dynamic properties of the tight junction barrier. Ann. N. Y. Acad. Sci. 2012, 1257, 77-84. [CrossRef]

41. Shashikanth, N.; Rizzo, H.E.; Pongkorpsakol, P.; Heneghan, J.F.; Turner, J.R. Electrophysiologic Analysis of Tight Junction Size and Charge Selectivity. Curr. Protoc. 2021, 1, 143. [CrossRef]

42. Chan, J.Y.; Takeda, M.; Briggs, L.E.; Graham, M.L.; Lu, J.T.; Horikoshi, N.; Weinberg, E.O.; Aoki, H.; Sato, N.; Chien, K.R.; et al. Identification of cardiac-specific myosin light chain kinase. Circ. Res. 2008, 102, 571-580. [CrossRef]

43. Cai, X.L.; Tanada, Y.; Bello, D.G.; Fleming, C.J.; Alkassis, F.F.; Ladd, T.; Golde, T.; Koh, J.; Chen, S.; Kasahara, H. Cardiac MLC2 kinase is localized to the Z-disc and interacts with $\alpha$-actinin2. Sci. Rep. 2019, 9, 12580. [CrossRef]

44. Xiao, K.; Cao, S.; Jiao, L.; Song, Z.; Lu, J.; Hu, C. TGF-beta1 protects intestinal integrity and influences Smads and MAPK signal pathways in IPEC-J2 after TNF-alpha challenge. Innate Immun. 2017, 23, 276-284. [CrossRef] [PubMed]

45. Poritz, L.S.; Garver, K.I.; Tilberg, A.F.; Koltun, W.A. Tumor necrosis factor alpha disrupts tight junction assembly. J. Surg. Res. 2004, 116, 14-18. [CrossRef]

46. Baker, O.J.; Camden, J.M.; Redman, R.S.; Jones, J.E.; Seye, C.I.; Erb, L.; Weisman, G.A. Proinflammatory cytokines tumor necrosis factor-alpha and interferon-gamma alter tight junction structure and function in the rat parotid gland Par-C10 cell line. Am. J. Physiol. Cell Physiol. 2008, 295, C1191-C1201. [CrossRef] [PubMed]

47. Mankertz, J.; Amasheh, M.; Krug, S.M.; Fromm, A.; Amasheh, S.; Hillenbrand, B.; Tavalali, S.; Fromm, M.; Schulzke, J.D. TNFalpha up-regulates claudin-2 expression in epithelial HT-29/B6 cells via phosphatidylinositol-3-kinase signaling. Cell Tissue Res. 2009, 336, 67-77. [CrossRef] [PubMed]

48. Amoozadeh, Y.; Dan, Q.; Xiao, J.; Waheed, F.; Szaszi, K. Tumor necrosis factor-alpha induces a biphasic change in claudin-2 expression in tubular epithelial cells: Role in barrier functions. Am. J. Physiol. Cell Physiol. 2015, 309, C38-C50. [CrossRef]

49. Zhang, C.; Yan, J.; Xiao, Y.; Shen, Y.; Wang, J.; Ge, W.; Chen, Y. Inhibition of Autophagic Degradation Process Contributes to Claudin-2 Expression Increase and Epithelial Tight Junction Dysfunction in TNF-alpha Treated Cell Monolayers. Int. J. Mol. Sci. 2017, 18, 157. [CrossRef] [PubMed]

50. Rosenthal, R.; Milatz, S.; Krug, S.M.; Oelrich, B.; Schulzke, J.D.; Amasheh, S.; Günzel, D.; Fromm, M. Claudin-2, a component of the tight junction, forms a paracellular water channel. J. Cell Sci. 2010, 123 Pt 11, 1913-1921. [CrossRef] [PubMed]

51. Radloff, J.; Cornelius, V.; Markov, A.G.; Amasheh, S. Caprate Modulates Intestinal Barrier Function in Porcine Peyer's Patch Follicle-Associated Epithelium. Int. J. Mol. Sci. 2019, 20, 1418. [CrossRef] [PubMed] 
52. Radloff, J.; Falchuk, E.L.; Markov, A.G.; Amasheh, S. Molecular Characterization of Barrier Properties in Follicle-Associated Epithelium of Porcine Peyer's Patches Reveals Major Sealing Function of Claudin-4. Front. Physiol. 2017, 8, 579. [CrossRef] [PubMed]

53. Markov, A.G.; Fedorova, A.A.; Kravtsova, V.V.; Bikmurzina, A.E.; Okorokova, L.S.; Matchkov, V.V.; Cornelius, V.; Amasheh, S.; Krivoi, I.I. Circulating Ouabain Modulates Expression of Claudins in Rat Intestine and Cerebral Blood Vessels. Int. J. Mol. Sci. 2020, 21, 5067. [CrossRef] [PubMed] 